\title{
The Open Source Biotechnology Movement: Is It Patent Misuse?
}

\author{
Robin Feldman*
}

\section{INTRODUCTION}

In the field of biotechnology, fledgling efforts are under way to establish open source projects. ${ }^{1}$ Borrowing concepts from the open source software movement, these projects create cooperative exchanges in which life science inventions are openly available to a broad research community. ${ }^{2}$ The projects

* Assistant Professor, U.C. Hastings College of the Law. I am grateful to Margreth Barrett, Dan Burk, Larry Lessig and Brad Rosenblatt for their comments on prior drafts. I am also indebted to Amy Hsaio and Charlie Chou for their research assistance.

1. See Stephen M. Maurer et al., Finding Cures for Tropical Diseases: Is Open Source an Answer?, in BIOTECHNOLOGY: ESSAYS FROM ITS HEARTLAND 33, 33-36 (Lynn Yarris ed., 2004) (discussing convergence of computing, biology, and open source for drug discovery), available at http://www.bayeconfor.org/pdf/BioTechReport.pdf; see also ABOUT THE INTERNATIONAL HAPMAP PROJECT [hereinafter HAPMAP PROJECT] (promoting utilization of open source techniques in developing a haplotype map of the human genome), at http://www.hapmap.org/abouthapmap.html (last modified June 4, 2004); BIOINFORMATICS.ORG, 2002 ORGANIZATION PLAN (explaining the mission of Bioinformatics.Org is "providing free and open resources for research, development and education"), at http://bioinformatics.org/about/plan20020920.pdf (Sept. 20, 2002); Pamela Jones, Interview: Public Patent Foundation's Dan Ravicher (explaining the Public Patent Foundation's goal of developing a system of protected commons for markets that are hampered by the presence of so many patent rights that it is difficult for researchers to operate), at http://lwn.net/Articles/64378/ (Dec. 23, 2003); Graeme O'Neill, 'Open-Source Biology' Stance Earns International Honour, AUSTRALIAN BIOTECHNOLOGY NEWS (describing BIOS), at http://www.cambia.org/downloads/Biotechnology_News_Dec_03.pdf (Mar. 12, 2003); Anna Salleh, Push to Free up Biotech Tools for All, ABC SCIENCE ONLINE (describing plans to assemble groups of enabling technologies that together provide the pieces necessary for a particular form of research investigation), at http://www.abc.net.au/science/news/stories/s999733.htm (Dec. 1, 2003). See generally An Open-source Shot in the Arm?, ECONOMIST, June 10, 2004, at 17 (discussing open source in biotechnology), available at http://www.economist.com/displaystory.cfm?story_id=2724420.

2. See, e.g., HAPMAP PROJECT, supra note 1 (describing the HapMap 
are aimed at solving problems in underserved communities, cutting through patent thickets, and ensuring that the biotechnology tools required for research and innovation are openly available. ${ }^{3}$

Building on the software notion of "copyleft," some open source biotechnology projects use the power of the patent system to ensure that the core technology of the project and any innovations remain openly available. For example, under ordinary principles of patent law, those who make improvements in the core technology would be entitled to apply for patent rights on the improvements. ${ }^{4}$ As the technology advances, these improvement patents could lead to rights splintering in which so many people hold pieces of rights to a particular technology that access is hindered. In response to this problem, open source biotechnology projects often require participants to agree that advances in the technology must remain as openly available as the original technology. ${ }^{5}$

Such agreements may implicate the doctrine of patent misuse. Patent misuse is defined as an impermissible attempt to expand the time or scope of the patent beyond the patent grant. ${ }^{6}$ It includes attempts to expand the patent power to things not included in the teachings of the original patent. Improvements in the core technology may not be within the teachings of the original patent. Thus, when open source

Project's goal of ensuring biotechnology tools are openly available).

3. See id.; Jones, supra note 1; see also Maurer, supra note 1.

4. See Gen. Elec. Co. v. Wabash Appliance Corp., 304 U.S. 364, 368 (1938) (noting "most inventions represent improvements on some existing article, process or machine"); Chiron Corp. v. Genentech, Inc., 268 F. Supp. $2 d$ 1148, 1155 (E.D. Cal. 2002) ("Patents are and should be granted to later inventors upon nonobvious improvements."), reh'g denied, 2004 U.S. App. LEXIS 12762 (Fed. Cir. 2004).

5. See, e.g., International HapMap Project Public Access License, [hereinafter PUBLIC ACCESS LICENSE] (requiring that users agree to not reduce others' access to the data and to share the data only with others who have made the same agreement), at http://www.hapmap.org/cgiperl/registration\#liTerms (Aug. 2003); see also O'Neill, supra note 1 (explaining users agree to grant back any improvements in the core technology and to make such improvements freely available to all others on the same terms that BIOS provided for the original core technology).

6. See Blonder-Tongue Labs., Inc. v. Univ. of Ill. Found., 402 U.S. 313, 343 (1971) (noting that the Court has condemned attempts to broaden the physical or temporal scope of the patent monopoly), remanded on other grounds, 334 F. Supp. 47 (N.D. Ill. 1971), affd, 465 F.2d 380 (7th Cir. 1972), cert. denied, 409 U.S. 1061 (1972); see generally 6 DONALD S. CHISUM, CHISUM ON PATENTS $§ 19.04$ (2003) (discussing patent misuse). 
biotechnology licenses require that advances in the technology must be made available to others on the same open terms as the original technology, the open source group may be using the power of the patent grant to reach an invention outside the original patent. When a patent holder appears to expand the scope of the patent beyond the patent grant, the question is whether the behavior is impermissible, as measured by the tests within the patent misuse doctrine.

In recent years, the Federal Circuit has revised the doctrine of patent misuse to mirror the federal antitrust laws. ${ }^{7}$ The Federal Circuit currently tests for patent misuse by looking for anticompetitive effects through application of the antitrust rule of reason. ${ }^{8}$

Despite the Federal Circuit's recent focus, relevant legislative and judicial precedents suggest that patent misuse should be tested by reference to patent policy and not antitrust law. ${ }^{9}$ Under this approach, patent misuse in open source biotechnology arrangements would be evaluated based on whether the effects of the behavior are inconsistent with patent policy. This article applies both of these tests to determine whether open source arrangements should be considered patent misuse.

The primary goal of the patent system is to promote the progress of science for the public benefit. ${ }^{10}$ As the United States Supreme Court explained in 1945, "[t]he primary purpose of our patent system is not reward of the individual but the advancement of the arts and sciences. Its inducement is

7. See Robin C. Feldman, The Insufficiency of Antitrust Analysis for Patent Misuse, 55 Hastings L.J. 399, 421-31 (2003) (discussing development of the law in the Federal Circuit).

8. See, e.g., Mallinckrodt, Inc. v. Medipart, Inc., 976 F.2d 700, 708 (Fed. Cir. 1992) (holding that in a patent misuse inquiry, the appropriate criterion is whether the patent holder has ventured beyond the patent grant and into behavior having an anticompetitive effect not justifiable under the rule of reason); see also Va. Panel Corp. v. MAC Panel Co., 133 F.3d 860, 868-69 (Fed. Cir. 1997) (evaluating Mallinckrodt, Inc. criteria and identifying certain practices constituting per se patent misuse), cert. denied, 525 U.S. 815 (1998); C.R. Bard, Inc. v. M3 Sys. Inc., 157 F.3d 1340, 1372 (Fed. Cir. 1998) (evaluating Mallinckrodt, Inc. criteria), reh'g denied 161 F.3d 1380 (Fed. Cir. 1998), cert. denied, 526 U.S. 1130 (1999); B. Braun Med., Inc. v. Abbott Labs., 124 F.3d 1419, 1426 (Fed. Cir. 1997) (evaluating Mallinckrodt, Inc. criteria); Bayer AG v. Housey Pharm., Inc., 228 F. Supp. 2d 467, 469 (D. Del. 2002) (applying the Federal Circuit test), aff'd, 366 F.3d 1348 (Fed. Cir. 2004).

9. See Feldman, supra note 7.

10. See U.S. ConsT. art. I, § 8, cl. 8. 
directed to disclosure of advances in knowledge which will be beneficial to society; it is not a certificate of merit, but an incentive to disclosure." 11 To accomplish this ultimate goal, the patent system encourages innovation by granting inventors limited rights to exclude others from their invention. ${ }^{12}$ The patent system grants these rights recognizing that there may be undesirable effects in the short run which will be offset by the system's ability to spur innovation over the long run. ${ }^{13}$

As a general matter, the open source system is consistent with patent policy. Accelerating the moment at which knowledge is widely available is consistent with patent policy's design to bring inventions into the public domain for the public benefit.

On a more detailed level, however, the open source system threatens to clash with patent policy. The patent system uses economic rewards to promote invention. If the open source system reduces the economic reward available to downstream inventors, this reduction may decrease the amount of long-term innovation. A decrease in long-term innovation would be inconsistent with patent policy.

Such an analysis, however, fails to consider all of the effects throughout the system across time. Although open source biotechnology may decrease some downstream economic returns, it increases downstream non-economic rewards. In addition, open source licensing may increase the level of downstream innovation by encouraging the exploitation of certain types of untapped. Finally, open source arrangements decrease the harms of the current patent system by reducing patent thickets and avoiding the short-term restriction of supply that one would expect under traditional patent licensing. For example, in granting a patent, the patent

11. Sinclair \& Carroll Co. v. Interchemical Corp., 325 U.S. 327, 330-31 (1945).

12. See Kewanee Oil v. Bicron Corp., 416 U.S. 470, 480 (1974) (explaining that the patent laws carry out the Constitutional mandate to "promote this progress by offering a right of exclusion for a limited period as an incentive to inventors to risk the often enormous costs in terms of time, research, and development").

13. See Jay P. Kesan \& Marc Banik, Patents as Incomplete Contracts: Aligning Incentives for R\&D Investment with Incentives to Disclose Prior Art, 2 WASH. U. J.L. \& POL'Y 23, 23-24 (2000) (noting that patents "impose social costs such as reduced levels of competition or wasteful design-around efforts by competitors" but also create an incentive to invest in research and development that leads to innovation). 
holder's ability to exclude others from making, using, or selling the invention will suppress competition and restrict supply of the invention, at least during the patent term. ${ }^{14}$ Open source inventions, which are openly available from the start, do not create the same type of restriction of supply. The overall effect of the open source system is to increase the supply of innovation and the speed at which such innovation is available for the public benefit, effects that are consistent with patent policy.

If patent misuse is analyzed by testing for anticompetitive effects under the antitrust rule of reason, the results would be the same although the logic would differ at some points. Finding anticompetitive effects under the rule of reason requires finding market power, anticompetitive effects, and proof that the anticompetitive effects outweigh any procompetitive benefits. ${ }^{15}$

Many open source products would not have market power in a properly defined market, given the availability of substitutes. For example, the open source software Linux does not have market power in the operating system market given competition from other operating systems such as Windows. If an open source group did possess market power, any anticompetitive effects of open source would have to be weighed against the pro-competitive effects.

One might argue that open source arrangements could be characterized as an attempt by the original open source group to prevent the development of a downstream product that would be available on different terms. Such behavior could be described as an attempt to reduce competition, which could restrict supply in relevant markets. Behavior that restricts supply may be considered anticompetitive under the antitrust rule of reason.

The open source group, however, is not trying to restrict the supply of available products. It is trying to increase the supply of biotech tools that are available by ensuring that the

14. See Kenneth J. Arrow, Economic Welfare \& the Allocation of Resources for Invention, in THE RATE AND DIRECTION OF INVENTIVE ACTIVITY: ECONOMIC AND SOCIAL FACTORS 609, 617 (Nat'l Bureau of Econ. Research ed., 1962) (noting that patent rights produce underutilization of information).

15. See Bd. of Trade v. United States, 246 U.S. 231, 238 (1918) ("Every agreement concerning trade, every regulation of trade, restrains ... The true test of legality is whether the restraint imposed is such as merely regulates and perhaps thereby promotes competition or whether it is such as may suppress or even destroy competition."). 
tools in their most advanced incarnation remain openly available. Thus, the effects of the open source system are better characterized as increasing rather than reducing the supply of relevant products.

Finally, any anticompetitive effects of the open source behavior would be outweighed by the pro-competitive effects of reducing patent thickets and promoting the creation and dissemination of ideas without a short-term restriction of supply. Thus, the effects of the open source biotechnology system should not be considered anticompetitive under the antitrust rule of reason, and therefore should not constitute patent misuse.

Part I of this article describes the current open source biotechnology movement and its predecessor, the open source software movement. Part II describes the doctrine of patent misuse. Part III compares open source biotechnology licensing to three traditional patent licensing arrangements: field of use restrictions, grantbacks, and reach-through royalties. It describes how the patent misuse doctrine has been applied to these arrangements. Part IV examines whether open source biotechnology practices should be considered patent misuse by examining whether the effects are inconsistent with patent policy. Part V considers whether open source should be considered patent misuse by examining whether the effects are anticompetitive as measured by the rule of reason. The article concludes that although open source biotechnology practices may implicate the doctrine of patent misuse, they should not be considered misuse under either test.

\section{THE OPEN SOURCE BIOTECHNOLOGY MOVEMENT}

\section{A. Current Open Source Biotechnology Projects}

The open source movement in biotechnology offers a structure for cooperative exchange in the development of life science products that are either bioengineered or produced as a result of techniques that involve biotechnology. The projects and their design are varied, but a common theme is the desire to make biotechnology advances available to a broad research community and to ensure that such open access continues. ${ }^{16}$

16. See, e.g., HAPMAP PROJECT, supra note 1 (explaining that the project will release all the data it produces so that any researcher can use the information and that those who are granted access to the information shall not 
The goal of many open source biotechnology projects is to counteract the phenomenon in certain research areas in which progress is hampered by the rights structure surrounding basic investigative tools. ${ }^{17}$ In some areas, the problem is simply the multitude of rights. For example, transferring a gene to a crop plant may require dozens of individually protected and discrete technologies. 18 Thus, a researcher trying to search for effective ways to genetically alter a particular plant for a particular trait will have to identify and obtain dozens of separate rights. Transaction costs are significant for commercial entities and may be overwhelming for poor nations, academic researchers, and other nonprofit entities that lack the resources to identify and negotiate all of the necessary rights. ${ }^{19}$

Scholars have used the term "patent thicket" to describe the problem of multiple overlapping rights that can hamper innovation by creating transaction barriers. ${ }^{20}$ Most scholars

restrict the access to the Genotype Database or the data that it contains); see also CAMBIA, Philosophy GUIDING FUTURE REGISTRATION TO USE THIS SITE ("CAMBIA's philosophy is to ensure that access to resources, including the IP Resource, is affordable to any and all users."), at http://www.cambiaip.org/legal/Terms/Payment_policy.htm (last visited Sept. 11, 2004) O'Neill, supra note 1 (explaining users agree to grant back any improvements in the core technology and to make such improvements freely available to all others on the same terms that BIOS provided for the original core technology thus assuring that a broad research community will have continued access to those tools).

17. See Kenneth Neil Cukier, Open Source Biotech: Can a Non-proprietary Approach to Intellectual Property Work in the Life Sciences? (stating the current patent system is an encumbrance), at http://www.cukier.com/writings/acumen-cukier-oct03.pdf (last visited Sept. 7, 2004); Jones, supra note 1 (listing "establishing patent commons within markets crippled by patent thickets" as one purpose of the Public Patent Foundation); Salleh, supra note 1; see also Rebecca S. Eisenberg, Bargaining over the Transfer of Proprietary Research Tools: Is this Market Failing or Emerging, in EXPANDING THE BOUNDARIES OF INTELLECTUAL PROPERTY 223, 225 (Rochelle Cooper Dreyfuss et al. eds., 2001) (noting some scientists must wait months or even years before gaining access to tools while their institutions wade through the many patent licensing agreements).

18. See Robin Feldman, CAMBIA BIOS Initiative: Biological Innovation for Open Society (Mar. 29 2004) [hereinafter BIOS Rockefeller Application] (unpublished manuscript submitted as an application to The Rockefeller Foundation) (on file with author).

19. See id.; Cukier, supra note 17, at 56; see also Lita Nelsen, The Rise of Intellectual Property Protection in the American University, 279 SCIENCE 1460, 1461 (1998) (noting that restricted availability or delays in exchange of research tools in biological research is a problem for university research).

20. See Carl Shapiro, Navigating the Patent Thicket: Cross Licenses, Patent Pools, and Standard-Setting, in 1 INNOVATION POLICY AND THE ECONOMY 1, 1-2 (Adam Jaffe et al. eds., 2001), available at 
and those reporting from the field agree that large numbers of rights hamper research and innovation, particularly in the biotechnology field. ${ }^{21}$ One study, however, has challenged the notion. ${ }^{22}$ John Walsh, Ashish Arora, and Wesley M. Cohen argue that firms simply work around the problem of multiple rights, for example, by moving offshore beyond the reach of patent rights, inventing around the rights, and using public research tools. ${ }^{23}$ In particular, they argue that academic researchers routinely ignore rights structures and that patent holders passively acquiesce. ${ }^{24}$ These options may not be available, however, to those with limited resources. Inventing around a patent and jurisdiction dodging are expensive. Ignoring rights is a risky enterprise, particularly for those who have limited resources to defend against a charge of infringement.

In areas not plagued by patent thickets, basic research tools may be controlled by one entity or a small group of entities. ${ }^{25}$ The cost of accessing these tools may be beyond the reach of nonprofit researchers and those targeting the problems of lesser developed nations, problems which are unlikely to generate great economic rewards.

Some open source biotechnology projects are designed as cooperative ventures in which a community of scientists works together to solve a common problem. For example, Stephen Maurer, Arti Rai, and Andrej Sali have proposed a "Tropical Disease Initiative" in which scientists from universities, laboratories, and corporations could work together on earlystage development of drugs to fight tropical diseases. ${ }^{26}$ The project would revolve around a web site in which individual

http://faculty.haas.berkeley.edu/shapiro/thicket.pdf.

21. See id.; see also supra notes 17-19.

22. John P. WALsh ET AL., REsearch TOOL PATENTING AND Licensing AND BIOMEDICAL INNOVATION, at www.heinz.cmu.edu/wpapers/download.jsp?3d=2003-2 (Dec. 11, 2002); John P. Walsh et al., Working Through the Patent Problem, 299 SCIENCE 1021 (2003), (summarizing the lack of impact of upstream patents on research), available at http://tigger.uic.edu/ jwalsh/WalshetalScience.pdf.

23. See WALSH ET AL., supra note 22, at 41.

24. See id. at 42 ; see also John P. Walsh et al., supra note 22.

25. See BIOS Rockefeller Application, supra note 18.

26. See Maurer, supra note 2; see also Janet Hope, Open Source Biotechnology? (2003) (unpublished Ph.D dissertation, Australian National University) (discussing the potential for application of open source approaches to biotechnology), at http://rsss.anu.edu.au/ janeth/OSBiotech.html (last visited Oct. 15, 2005). 
pages would focus on separate tasks such as identifying new drug targets, searching for new chemicals that affect targets already identified, and checking the feasibility of existing drugs on the targets. ${ }^{27}$ Identifying drug targets involves finding specific parts of the human molecular structure such as genes or proteins that play a role in the mechanism of a targeted disease process. ${ }^{28}$ For example, the genes that go awry in a particular cancer are often identified as drug targets in cancer research because they allow scientists to target the molecular mechanisms underlying the disease. ${ }^{29}$ In the Tropical Disease Initiative project, scientists would annotate a shared database each time they made a discovery related to the relevant drug targets, and the results could be discussed in internet chat rooms and at conferences. ${ }^{30}$

A similar effort is underway in the HapMap Project, which is developing a specialized map of the human genome. ${ }^{31}$ The goal of the project is to develop a map that describes not the standard sequence of human DNA but rather common patterns of human DNA variation. ${ }^{32}$ The project began in fall 2002 and is expected to take at least three years to complete. ${ }^{33}$ The information generated by the project is freely available, provided that those who access the data do not restrict the access of others. ${ }^{34}$

In particular, users must agree not to file patent applications for information contained in the database such as single nucleotide polymorphisms (SNPs). ${ }^{35}$ SNPs are sites in

27. See Mauer, supra note 1, at 34, 37.

28. See generally Jürgen Drews, Drug Discovery: A Historical Perspective, 287 SCIENCE 1960 (2000) (discussing the development of different types of drug targets and their uses).

29. See Jackson B. Gibbs, Mechanism-Based Target Identification and Drug Discovery in Cancer Research, 287 SCIENCE 1969, 1970 (2000); see also Aimee E. Belanger et al., PCR-Based Ordered Genomic Libraries: A New Approach to Drug Target Identification for Streptococcus pneumoniae, 46 ANTIMICROBIAL AGENTS \& CHEMOTHERAPY 2507, 2507 (2002) (describing the discovery process of drug targets to cure Streptococcus pneumoniae "by first determining which of the ordered amplicons yields resistant transformants and then examining the genetic content of the amplicon in question"), available at http://aac.asm.org/cgi/content/full/46/8/2507.

30. See Maurer, supra note 1, at 37 .

31. See HAPMAP PROJECT, supra note 1.

32. Id.

33. Id.

34. See PUBlic AcCess LiCEnse, supra note 5.

35. Id. 
the human genome where the DNA sequences of many individuals differ slightly. ${ }^{36}$ Users must also agree that any patents filed for particular uses of the SNPs or other data in the Genotype Database will be licensed on terms that allow others free access to the data in the Genotype Database for other purposes. ${ }^{37}$

Other projects, such as the Public Patent Foundation project, are envisioned as protected commons in which patent holders would agree to pool their technologies, which would then be freely available to all participants. ${ }^{38}$ The Public Patent Foundation plans to develop a system of protected commons for markets that are hampered by the presence of so many patent rights that it is difficult for any researchers, even those who hold patents themselves, to operate. 39

In each commons, patent holders would grant nonexclusive licenses to a public trust that would then make all of the technologies available to the participants. ${ }^{40}$ The commons would operate along the lines of a disarmament treaty that permits only bilateral participation. ${ }^{41}$ In other words, one cannot benefit from the patent commons without placing one's rights in the commons as well. ${ }^{42}$

Another project, the Biological Innovation for Open Society (BIOS) plans to operate as a combination of the cooperative and the protected commons approaches. ${ }^{43}$ BIOS plans to assemble groups of enabling technologies that together provide the pieces necessary for a particular form of research investigation. ${ }^{44}$ For example, a BIOS group, or node, might contain a core technology, or groups of technologies, necessary for introducing new genes into plants. Such technologies would not have to be superior to existing commercial technologies. They would just need to provide a sufficiently effective tool for engaging in the

36. See HAPMAP PROJECT, supra note 1 (describing single nucleotide polymorphisms).

37. See PUBLIC ACCESs LICENSE, supra note 5.

38. See Jones, supra note 1.

39. Id.

40. E-mail from Dan Ravicher, Executive Director, Public Patent Foundation, to Robin Feldman, Assistant Professor of Law, University of California Hastings College of the Law (Jan. 13, 2004, 11:34 PST) (on file with author).

41. Id.

42. $I d$.

43. Salleh, supra note 1 .

44. See id. 
basic research such that developing nations, small biotechnology companies, and public research agencies will be able to engage in research without becoming ensnared in current patent traps. ${ }^{45}$

BIOS founder Richard Jefferson uses a wheel-and-spoke analogy to describe his vision of groups of technologies that enable biotechnology research. According to this analogy, biological technologies are interdependent, requiring several key components to function, just as a wheel requires a number of spokes in order to operate. ${ }^{46}$ BIOS hopes that it will be able to provide participants with complete packages including all of the spokes. ${ }^{47}$

Although BIOS is in the planning phases, it has access to some technologies that may help propel its projects. BIOS is an outgrowth of the Center for the Application of Molecular Biology to International Agriculture (CAMBIA). BIOS now holds the rights to CAMBIA's intellectual property. ${ }^{48}$ Such technology includes D ArT, a patented genotyping, or gene mapping method, invented by one of CAMBIA's scientists. ${ }^{49}$ Other technologies include a method for introducing new genes into plants such that the resulting proteins will be expressed only in specific tissues such as roots, flowers, seeds, or leaves. ${ }^{50}$ This technique bypasses a host of patents that researchers otherwise would have to navigate and has been successfully used in a Chinese project to create transgenic rice lines that are being evaluated for characteristics such as reduced water use and disease resistance. 51

In addition to the technology already developed, BIOS plans to establish cooperative ventures similar to those envisioned by Maurer, Rai, and Sali. Individuals and agencies will be able to collaborate by creating technologies and working around existing blocks, with BIOS providing the cyberspace location and the structure for the exchange. ${ }^{52}$

45. See O'Neill, supra note 1.

46. BIOS Rockefeller Application, supra note 18

47. See id.

48. See Salleh, supra note 1.

49. See id.

50. See id.; O’Neill, supra note 1.

51. See O'Neill, supra note 1; see also Salleh, supra note 1 (describing CAMBIA's work toward developing an alternative to the proprietary Agrobacterium transformation technology).

52. See BIOS Rockefeller Application, supra note 18; see also Maurer, supra note 1. 
BIOS technologies will be available free of charge to anyone. ${ }^{53}$ Users will be required to sign a license agreeing to grant back any improvements in the core technology and to make such improvements freely available to all others on the same terms that BIOS provided for the original core technology. ${ }^{54}$ Without such an agreement, the core technology could lose its free access as those who improve the technology apply for proprietary rights to the improvements. Over time, the core technology would become as encumbered as current technologies. ${ }^{55}$

In contrast to improvements to the core research tool technologies, the BIOS license would permit users to patent any inventions created. The BIOS founder describes the license in the following fashion: "Th[e] license will say you agree to share improvements in the core technology. You can make your own applications as proprietary as you want; you can patent your invention. But the tools to do that must be a public good." 56

Some open source biotechnology projects are centered on bioinformatics, a type of technology at the intersection of biology and software. Bioinformatics uses software to generate and analyze data relating to bioscience research. ${ }^{57}$ Such projects tend to follow closely along the lines of their open source software predecessors. Software is created and improved through an unstructured cooperative process. License agreements frequently mirror those available for open source software. For example, several open source bioinformatics programming languages are available, including BioPerl, BioJava, Biopython, BioRuby, and others. ${ }^{58}$ These languages are available through standard open source software

53. See O'Neill, supra note 1.

54. See id.; Salleh, supra note 1

55. BIOS also plans a database project using its comprehensive publicaccess database that consists of the full text of patents relevant to agricultural biotechnology, both applications and patents granted, from the United States, European, and Australian jurisdictions with a user-friendly searchable interface. See BIOS Rockefeller Application, supra note 18.

56. Salleh, supra note 1.

57. See Edward N. Trifonov, Earliest Pages of Bioinformatics, 16 BIOINFORMATICS 5 (2000) (describing the early development of the field).

58. The Open Bioinformatics Foundation web site exists as a hub for supporting the languages. See Open Bioinformatics Foundation, http://www.open-bio.org (last visited Sept. 15, 2004). 
licenses. ${ }^{59}$ For example, BioJava is subject to the GNU Lesser General Public License, a license developed for open source software. 60 The license grants freedom to copy the program, modify it, and distribute it to others for free or for a fee. ${ }^{61}$ Among other things, the license requires that those who distribute or modify the program must make the source code available to other users and must make modified versions available on the same terms as the original version. ${ }^{62}$ Finally, the license requires that any patent license granted for a version of the original software must be consistent with the full freedom of use specified in the original license. ${ }^{63}$

Most open source biotechnology software projects are nonprofit ventures. Nevertheless, one South African company has developed a business model designed around open source biotechnology software. The company, Electric Genetics Corporation, has released its bioinformatics software under a free open source license and provides validation and support services for a fee. ${ }^{64}$

Open source biotechnology projects are at various stages of development. Some, such as the South African company and the bioinformatics programming languages, have actual products currently in use. ${ }^{65}$ Others, such as the HapMap Project, are under way and moving towards their research goals. Some, such as BIOS and the Public Patent Foundation, are in the active planning and design phases. Still others are in the early concept phase.

59. See the Open Bioinformatics Foundation web site at http://www.openbio.org for links to the languages and the relevant licenses.

60. See Open Bioinformatics Foundation, BioJava Project, at http://www.biojava.org/download/binaries/LICENSE (last modified July 2, 2001).

61. See GNU Lesser General Public License, at http://www.gnu.org/copyleft/lesser.html (last updated Nov. 27, 2000).

62. See id.

63. See id. For a list of other open source biotechnology projects, see Cukier, supra note 17.

64. See Cukier, supra note 17. In 2002, the company organized a "biohackathon," flying scores of open source programmers to South Africa to write code. Id. Kristen Philipkoski, Cure for South Africa's Ills, WIRED NEWs, Apr. 8, 2002, at http://www.wired.com/news/medtech/0,1286,51533,00.html (last visited Sept. 6, 2004). 


\section{B. Open Source Software: The Predecessor of the Open SOURCE BIOTECHNOLOGY MOVEMENT}

It is not surprising that the open source biotechnology projects farthest along tend to have significant bioinformatics elements. The open source biotechnology movement has its roots in the open source software movement, ${ }^{6} 6$ and the easiest transfer of principles occurs at the intersection of biology and software where programs and databases are developed for exploring and managing biotechnology information. ${ }^{67}$

66. For detailed discussions of the open source software movement, see generally RichARD STALlMAN, Free SOFTwARE, FrEe SOCIETY: SELECTED ESSAYS OF RICHARD STALlMAN (Joshua Gay, ed., 2002); Marcus Maher, Open Source Software: The Success of an Alternative Intellectual Property Incentive Paradigm, 10 FORDHAM INTELL. PROP. MEDIA \& ENT. L.J. 619 (2000) (tracing the success of open source in software); Christian H. Nadan, Open Source Licensing: Virus or Virtue?, 10 TEX. INTELL. PROP. L.J. 349 (2002) (advocating open source as a great opportunity to commercialize and listing approaches for businesses to take advantage of open source); Lawrence Lessig, The Limits in Open Code: Regulatory Standards and the Future of the Net, 14 BERKELEY TECH. L.J. 759 (1999) (suggesting that the open source movement will make it more difficult for the government to regulate the Internet); Joseph Scott Miller, Allchin's Folly: Exploding Some Myths About Open Source Software, 20 CARDOZO ARTS \& ENT. L.J. 491 (2002) (rebutting the idea that open source is bad for capitalism because it supports the underlying purpose of copyright by disseminating information); Patrick K. Bobko, Open-Source Software and the Demise of Copyright, 27 RUTGERS COMPUTER \& TECH. L.J. 51, 90 (2001) (arguing that open source software, by uncoupling the economic incentives from the creative process, has "subvert[ed] the foundation upon which the commercial software industry is built"); Mathias Strasser, A New Paradigm in Intellectual Property Law?: The Case Against Open Sources, 2001 STAN. TECH. L. REV. 4 (arguing that open source in copyright is flawed because it undermines the incentive purpose of copyrights by exposing commercial developers to too much risk); David S. Evans \& Bernard J. Reddy, Government Preferences for Promoting Open-Source Software: A Solution in Search of a Problem, 9 Mich. TEleCOMM. \& TECH. L. REV. 313 (2003) (arguing that software licensing is adequate thereby precluding any need for government to get involved and impose open source); Klaus M. Schmidt \& Monika Schnitzer, Public Subsidies for Open Source? Some Economic Policy Issues of the Software Market, 16 HARV. J.L. \& TECH. 473, 488 (2003) (warning that open source development may create "forking" so that different programs will not be compatible with each other); Yochai Benkler, Coase's Penguin, or, Linux and The Nature of the Firm, 112 YALE L.J. 369 (2002) (providing an interesting study of how the open source movement defies Coase's theory of organization, which states that production must be organized by the market or managerial hierarchy).

67. For a discussion of characteristics of the bioinformatics industry that are either well-suited or ill-suited for the open source model, see generally Open Source Genomics, Symposium on Bioinformatics and Intellectual Property Law, 8 B.U. J. SCI. \& TECH. L. 254 (2002) [hereinafter Symposium]; see also Maurer et al., supra note 1, at 33-35 (discussing the same set of issues 
The open source software movement is grounded in the notion that end users should have the ability to study, change, modify, and redistribute the software they use. ${ }^{68}$ Most software is distributed in the form of object code, a series of ones and zeroes that can be read by computers but is unintelligible to humans, even skilled programmers. ${ }^{69}$ In order to modify the software, a programmer needs the source code, which is a compilation of the ones and zeroes found in the object code into a language that can be understood by those skilled in the art of programming. 70 Without access to the source code, and the authorization to change it, end users must depend on the original software company to fix bugs, provide upgrades, and modify the program for individual requirements. ${ }^{71}$ In the fastpaced and individualistic world of software programming such an arrangement seems excruciatingly slow and insufficiently attuned to the advantages of, and desire for, free intellectual exchange. ${ }^{72}$

In contrast to this approach, open source pioneers developed a different model in which source code is distributed along with object code, and users are authorized to distribute and modify the program toward their individual ends. ${ }^{73}$ The most successful modifications are then reviewed and adopted by the broader user community.

In many open source software projects, a group of developers will operate loosely as project managers guiding the incorporation of new code into the evolving program. ${ }^{74}$ Some open source software programs have begun with a contribution of software which is then provided to the community on terms

in relationship to open source biotechnology projects); Hope, supra note 26. Although open source has flourished within the world of software development, it has appeared in other disciplines as well. See Thomas Goetz, Open Source Everywhere, WIRED MAGAZINE (Nov. 2003) (describing opensource-like approaches throughout history), available at http://www.wired.com/wired/archive/11.11/opensource.html. One commentator has suggested the following: "Coders, it could be argued, got to open source first only because they were closest to the tool that made it a feasible means of production: the Internet." Id.

68. See Nadan, supra note 66 , at 353.

69. See Joseph Scott Miller, Allchin's Folly: Exploding Some Myths About Open Source Software, 20 CARDOZO ARTS \& ENT. L.J. 491, 494 (2002).

70. See id.

71. See Nadan, supra note 66 , at 353 .

72. See Stallman, supra note 66 , at 16 .

73. See id. at 18, 20-21.

74. See Nadan, supra note 66 , at 352 . 
that allow modification and redistribution. ${ }^{75}$ Other open software programs begin as little more than an idea, which must then be developed into a project by the broader programming community. ${ }^{76}$

A key problem for the open source software movement is the challenge of ensuring that, after the source code is released to the public, it remains available for future users to modify and distribute. If developers simply renounce their copyrights and release the code into the public domain, those who make improvements would be able to make the improved version closed and proprietary. For example, one who modifies the original program by adding functionalities or fixing bugs could claim to have created a derivative work based on a product in the public domain.77 The second comer would then hold an independent copyright on the derivative work and could exercise that copyright by releasing the derivative program solely in a closed proprietary fashion. ${ }^{78}$ If this happened, the open source project could quickly degenerate. The best versions of the program might be proprietary, and the software could become closed.

Ensuring continued open access to the program requires a creative twist on the notion of copyright protection. Rather than releasing the information into the public domain, open source developers retain their right to control the product, exercising those rights only to the extent of trying to ensure that the product remains open for modification and distribution. For example, many open source software products are licensed under the GPL, which requires, among other things, that enhancements and derivatives must be made available on the same open use and distribution terms as the original software. ${ }^{79}$ This approach has been called "copyleft."

75. See, e.g., Maher, supra note 66, at 623-24 (describing Netscape's Mozilla license which controls its formerly closed browser software); Lessig, supra note 66, at 766 (noting Netscape's contribution of its browser code to an open source project).

76. See Maher, supra note 66, at 622-23 (describing the evolution of Linux).

77. See Miller, supra note 69, at 495.

78. See id.

79. See Maher, supra note 66, at 638; GNU General Public License, at http://www.fsf.org/copyleft/gpl.html (last visited Sept. 7, 2004). Other types of open source licenses include the Berkeley Software Distribution License and the EFF Open Audio License. See Open Source, at http://www.opensource.org/licenses/bsd-license.php (last visited Sept. 7, 2004); Electronic Frontier Foundation, at www.eff.org/IP/Open_licenses/eff.oal.html) 
The phrase reflects the notion that participants use the copyright system, which normally operates to restrict the use of works, in a manner that keeps works free from restrictions. ${ }^{80}$

The currency for those who participate in the open source software movement is different from traditional economic rewards. Programmers volunteer their time and ideas and successful programmers are rewarded with prestige in the programming community. 81 In addition, prestige within the programming community may translate into traditional economic rewards in that programmers who demonstrate skills in the open source community can trade on that reputation in the job market.82 Other rewards include the satisfaction of contributing to a body of knowledge and the joy of participating in an intellectual exchange. One author describes these phenomena in the following fashion:

Most who use and improve [open source software] do so with the hope of making a unique and lasting contribution to the body of knowledge or, in hacker terminology, coming up with a "cool" hack. For example, only hours after Netscape had released the code for its Internet browser, a group of Australian programmers "had attached a cryptographic add-on" that enabled Netscape's program to conduct secure Internet transactions. The Australians "were paid handsomely - but not with money. The programmers . . got paid in respect from the rest of the programming community and in the satisfaction of turning out an elegant useful bit of software." 83

The wish to participate in, and contribute to, the advancement of science may explain why individuals participate in National Aeronautics and Space Administration's open source Mars project. The project, which is part of the Mars mission, asks volunteer "clickworkers" to help identify millions of craters and draw a map of the planet. 84

Other rewards for participation in open source projects may include the appeal of altruism. For example, the ThinkCycle project focuses on finding engineering solutions to problems that plague underserved communities and the environment. ${ }^{85}$ ThinkCycle, an academic nonprofit project, is

(last visited Sept. 7, 2004).

80. STALLMAN, supra note 66, at 20-21.

81. See Symposium, supra note 67, at 256; see, e.g., Maher, supra note 66, at $631-33$.

82. See Maher, supra note 66 , at 632 .

83. Bobko, supra note 66 , at 83.

84. See Goetz, supra note 67.

85. See ThinkCycle, at http://www.thinkcycle.org/about (last visited Sept. $24,2004)$. 
the brainchild of a group of Massachusetts Institute of Technology students. ${ }^{86}$ It operates as an open source webbased design collaborative. ${ }^{87}$ Among other projects, ThinkCycle has addressed a problem facing health care volunteers trying to fight cholera. The challenge was to develop a kit to instruct local people on the use and calibration of IV equipment. ${ }^{88}$ Easy-to-use systems cost $\$ 2,000$ per patient, putting these systems beyond the reach of most communities facing cholera outbreaks. ${ }^{89}$ Less expensive systems were available but required skilled workers to administer them. ThinkCycle designed a system that cost $\$ 1.25$ to manufacture and could be administered by unskilled workers. ${ }^{90}$ Project volunteers presumably were motivated at least in part by the intangible rewards of helping desperately ill people in poor communities.

Although most open source software endeavors offer intangible rewards to participants, not all eschew the more traditional economic rewards. For example, some companies have been built on the concept of providing peripheral products and services to support the open source product. For example, the Linux operating system was developed, and is expanded and maintained in an open source, collaborative process. Red Hat, Inc. provides software support services and easy-to-use bundles of Linux for a fee.91 Red Hat did not develop the software on which Linux operates nor does it employ the programmers that maintain it. ${ }^{92}$ Red Hat does not control the future development of Linux and cannot direct any improvements made to it. ${ }^{93}$ Despite these limitations, Red Hat has generated sufficient business to "win the approval of financial markets and maintain [significant] market capitalization." 94

In short, the desire to have software that can be freely

86. See id.

87. See Lee Ridgway, ThinkCycle: Reaching Out to Solve Real-World Problems, 17 INFO., SERV. \& TECH. THROUGHOUT MIT 3, at 1 (Jan./Feb. 2002), available at $\mathrm{http} / / /$ web.mit.edu/is/isnews/v17/n03/170301.html.

88. See id. at 2 .

89. See Goetz, supra note 67.

90. See id.

91. See Red Hat, at http://www.redhat.com (last visited Apr. 15, 2004); See David McGowan, Legal Implications of Open-Source Software, 2001 U. ILL. L. REV. 241, 242-43 (2001).

92. McGowan, supra note 91 , at 242.

93. Id.

94. Id. 
understood, accessed, and modified has spawned cooperative ventures in software development. Biotechnology researchers are borrowing and adapting these approaches in efforts to engage in collaborative research that can solve problems facing poor communities, trim patent forests, and make the tools of biotech innovation freely available.

Following the notion of copyleft, some of the open source biotechnology projects use the power of the intellectual property system to ensure that the technologies they develop, and any future modifications, are no more restricted than the original technology. In the biotechnology arena, however, the intellectual property rights regime is frequently patent rather than the copyright regime utilized in open source software. ${ }^{95}$ In the patent context, the patent holder exercises its patent rights by requiring that those who use or modify the research technology agree to maintain the open nature of the core technology and any improvements.

\section{PATENT MISUSE}

\section{A. What Is Patent Misuse?}

Patent misuse is defined as an impermissible attempt to extend the time or scope of the patent grant.96 A patent is intended to convey exclusive rights in an invention, but those rights are limited by the twenty-year term of the grant and by

95. Copyright is not the exclusive rights regime for open source software, nor is patent the exclusive rights regime for open source biotechnology. Software can receive patent protection in some circumstances as well as copyright protection. Compare 1 DONALD S. CHISUM, CHISUM ON PATENTS $\S$ $1.03[6][i]$, at 209 (2003) (explaining that some software is now patentable), with Pamela Samuelson, CONTU Revisited: The Case Against Copyright Protection for Computer Programs in Machine-Readable Form, 1984 DUKE L. J. 663, 665 (1984) (noting that software in machine-readable form is copyrightable). Similarly, to the extent that a biotechnology invention includes software, the software may be eligible for copyright protection. In addition, one scholar has argued that DNA sequences should be copyrightable as well as patentable. See Irving Kayton, Copyright in Living Genetically Engineered Works, 50 GEO. WASH. L. REV. 191 (1982). But see James G. Silva, Copyright Protection of Biotechnology Works: Into the Dustbin of History?, 2000 B.C. INTELL. PROP. \& TECH. Forum 012801 93 (2000) (“[C]opyright protection for biotechnology works is either impermissible or of severely limited scope."), at http://infoeagle.bc.edu/bc_org/avp/law/st_org/iptf/articles/ index.html; MICHAEL EPSTEIN, Protecting Biotechnology, in MODERN INTELLECTUAL PROPERTY LAW 219, 230-31 (Supp. 1988).

96. See, e.g., Blonder-Tongue Labs., Inc. v. Univ. of Ill. Found., 402 U.S. 313, 343-44 (1971); 6 CHISUM, supra note 6, § 19.04, at 427. 
the boundaries of the invention that was created.

Acts that may constitute misuse include requiring patent licensees to buy unpatented goods, prohibiting production or sale of competing goods, and conditioning the license of one patent on accepting a different license as well. ${ }^{97}$ The finding of misuse rests on the notion that the patent holder is using its rights to garner a return from something not in the patent. The patent holder thereby improperly extends the scope of the patent to things not included in the teachings of the patent holder's invention.

For example, in Zenith Radio v. Hazeltine, ${ }^{98}$ the Supreme Court considered a package license in which the licensor would not grant licenses to individual patents, but insisted on granting licensees the rights to use any of the company's 500odd patents in any of the licensee's products for a five-year term. ${ }^{99}$ The licensor reserved royalties on the total sales of the licensee's products regardless of whether the licensed patents were used in the manufactured products. ${ }^{100}$ The Supreme Court held that such coercive package licensing constituted patent misuse. 101 By requiring royalty payments on products that did not incorporate any of the teachings of the patent, the agreement impermissibly allowed the patent holder to extend the scope of the patent beyond the invention specified in the patent. 102 In other words, the patent holder was using its patent to get a return on a product beyond what the patent holder had invented.

A finding of patent misuse has serious implications for a patent holder. If a patent holder is found to have engaged in misuse, the patent is unenforceable until the misuse ends and the effects of the behavior have dissipated. ${ }^{103}$ Until the effects have dissipated, the patent cannot be enforced against any

97. See 6 CHISUM, supra note 6, § 19.04[3], at 451-534 (describing classic acts of misuse).

98. 395 U.S. 100 (1969).

99. See Zenith Radio Corp. v. Hazeltine Research, Inc., 395 U.S. 100, 104, 133-34 (1969).

100. Id. at 134 .

101. Id. at 139-40.

102. See id. at 135-36; 6 CHISUM, supra note 6 , $\S 19.04[3][c]$, at 467-72 (discussing coercive package licenses).

103. See, e.g., C.R. Bard, Inc. v. M3 Sys., Inc., 157 F.3d 1340, 1372 (Fed. Cir. 1998) ("Patent misuse arises in equity, and a holding of misuse renders the patent unenforceable until the misuse is purged; it does not, of itself, invalidate the patent."); 6 CHISUM, supra note $6, \S 19.04$, at 427. 
infringer, not just the one who brought the claim of misuse. 104

The danger of a charge of patent misuse is amplified by the relaxed standing rules of the doctrine, which date back to a series of Supreme Court decisions in the 1940s.105 Under the patent misuse doctrine, patent misuse can be raised as a defense to infringement even if the defendant is not the one who has suffered damage from the alleged misuse. ${ }^{106}$ As a result, many parties may have standing to raise a claim of patent misuse, a far wider group, for example, than those who would have standing to raise antitrust violations as a defense. ${ }^{107}$

The patent misuse doctrine emerged in the late nineteenth and early twentieth centuries during the period in which state and federal antitrust laws were taking hold. ${ }^{108}$ Patent misuse and antitrust law share an intertwined history and intersect at a variety of doctrinal points. 109 Despite the intersections, a defendant claiming patent misuse need not show a violation of the antitrust laws. ${ }^{110}$

In addition, not all terms that appear to extend the time or scope of the patent grant would constitute misuse. For example, the Supreme Court has noted that although certain

104. 6 CHISUM, supra note $6, \S 19.04$, at 427.

105. See Morton Salt Co. v. G.S. Suppiger Co., 314 U.S. 488 (1942); Mercoid Corp. v. Mid-Continent Inv. Co., 320 U.S. 661, 665-66 (1944); Recent Decisions, Trade Regulation - Attempted Partial Monopoly of Unpatented Product as Defense to Suit for Direct Infringement, 42 COLUM. L. REV. 882, 884 (1942).

106. See Mark A. Lemley, The Economic Irrationality of the Patent Misuse Doctrine, 78 CAL. L. REV. 1599, 1610 (1990). See also Note, Is the Patent Misuse Doctrine Obsolete? 110 HARV. L. REV. 1922, 1939 (1997) (arguing that the more lenient standing requirement should be kept to maintain increased judicial scrutiny of patents).

107. See, e.g., Ill. Brick Co. v. Illinois, 431 U.S. 720, 728-29 (1977) (holding that only a direct purchaser, not others in the chain of manufacture and distribution, may sue for antitrust damages under $\S 4$ of the Clayton Act); Duplan Corp. v. Deering Miliken, Inc., 444 F. Supp. 648, 699 (D.C.S.C. 1977) (finding a misuse violation but not an antitrust violation because infringers were not damaged by the patent holder's improper actions); see generally Albert R. Henry, Limitations Inherent in the Grant of Letters Patent, 27 CORNELL L. Q. 214, 235-36 (1942).

108. See Feldman, supra note 7, at 403.

109. For a general description of the development of patent misuse doctrine and its intersection with antitrust doctrines, see id. at 402-31.

110. See, e.g., Morton Salt, 314 U.S. at 494; see also Va. Panel Corp. v. Mac Panel Co., 133 F.3d 860, 872 (Fed. Cir. 1997) (noting that a violation of the antitrust laws requires "more exacting proof than suffices to demonstrate patent misuse"). 
extended payment agreements would bring a return beyond the time of the grant, such arrangements would not constitute patent misuse if they were reasonable business arrangements entered into for the convenience of both parties.111 The line for establishing whether behavior that appears to stretch the temporal or substantive boundaries of the grant constitutes misuse is unclear, however, and such questions presumably would fall within a general analysis of what constitutes patent misuse.

Over the last decade, the U.S. Court of Appeals for the Federal Circuit has the doctrine of patent misuse, adding elements and tests that mirror the federal antitrust laws. ${ }^{112}$ For example, the Federal Circuit has expanded the definition of patent misuse by adding the requirement that the improper extension of the time or scope of the patent must be "with anticompetitive effect."113 In addition, the Federal Circuit has established that courts should use antitrust law's rule of reason test to determine whether a particular behavior constitutes patent misuse. ${ }^{114}$ Thus, the Federal Circuit would test patent misuse in general, and open source biotechnology licenses in particular, by looking for anticompetitive effects under the antitrust rule of reason.

The classic treatise on antitrust describes the rule of reason as requiring a series of steps. ${ }^{115}$ First, the plaintiff has the initial burden of showing that the behavior restrains competition in a specific market. Second, if the plaintiff meets this initial burden, the burden shifts to the defendant to show that its behavior serves legitimate objectives. Third, if the defendant meets that burden, the plaintiff may show that the defendant could meet its objective using less restrictive

111. See Zenith Radio Corp. v. Hazeltine Research, Inc., 395 U.S. 100, 13637 (1969).

112. See Feldman, supra note 7, at 425-31; see also Robert J. Hoerner, The Decline (And Fall?) of the Patent Misuse Doctrine in the Federal Circuit, 69 ANTITRUsT L.J. 669, 672-673 (2002); Patricia A. Martone \& Richard M. Feustel, Jr., The Patent Misuse Defense - Does it Still Have Vitality?, in INTELL. PROP. ANTITRUST 217, 250 (2002).

113. See Feldman, supra note 7, at 426; Mallinckrodt, Inc. v. Medipart, Inc., 976 F.2d 700, 708 (Fed. Cir. 1992); Va. Panel, 133 F.3d at 869; C.R. Bard, Inc. v. M3 Sys., Inc., 157 F.3d 1340, 1372 (Fed. Cir. 1998); B. Braun Med., Inc. v. Abbott Labs, 124 F.3d 1419, 1426 (Fed. Cir. 1997).

114. See supra note 113; see also Windsurfing Int'l, Inc. v. AMF, Inc., 782 F.2d 995, 1001-02 (Fed. Cir. 1986); Bayer AG v. Housey Pharms., Inc., 228 F. Supp. 2d 467 (D. Del. 2002) (applying the Federal Circuit test).

115. Feldman, supra note 7, at 422 n.113. 
alternatives. And finally, the court must weigh the harms and benefits of the restraint with the plaintiff bearing the burden to show that the restraint is unreasonable on balance. ${ }^{116}$

I have argued that the Federal Circuit's doctrine is inconsistent with the relevant legislative and judicial precedents, which suggest that patent misuse should be tested by reference to patent policy, not antitrust law. ${ }^{117}$ In addition to the dictates of precedent, using antitrust rules to test for patent misuse will be inadequate because the policies underlying patent misuse are not confined to limiting the types of monopoly harms that antitrust law addresses. ${ }^{118}$ Thus, rather than asking whether the effects of the behavior are consistent with antitrust policy, courts should ask whether the effects of the behavior are consistent with patent policy. ${ }^{119}$

\section{B. The Patent Misuse Problem for Open Source BIOTECHNOLOGY}

Open source biotechnology projects face the challenge of keeping research tools and other inventions available to a broad research community even as the technology advances. Under ordinary principles of patent law, however, those who make novel and nonobvious improvements in the core technology would be entitled to apply for patents on their improvements. This assumes, of course, that the advancement meets all of the other requirements of patentability, including utility, enablement, and patentable subject matter. If innovators patent their improvements, the best way of utilizing the technology would then be controlled by multiple parties, leading back to the problem of research techniques shrouded in overlapping rights. As an added problem, any one of the multiple parties could demand a royalty that places the full technique beyond the reach of many who address the problems of poor communities.

Open source biotechnology projects may face less risk from subsequent innovators than open source software projects. Biotech research tools frequently are protected by patents rather than copyrights, and the standard for patentability is

116. See id.

117. Id. at 421.

118. Id. at 431.

119. For a more comprehensive discussion of the theories outlined below, see Feldman, supra note 7 , at $431-49$. 
much higher than the standard for copyrightability.120 For example, an improvement in a program that fixes a bug might meet the standard for copyrightability as a derivative work but not the nonobviousness standard for patentability. 121 Thus, one would expect open source biotechnology projects to face fewer people who could claim rights to patentable improvements on the technology than open source software projects. Although the pool may be smaller, open source biotechnology projects still face the risk that subsequent improvers may claim patent rights to improvements. In addition, to the extent that the biotech project includes copyrightable elements, the project incurs the same risks as traditional open source software.

Many of the open source biotech licensing agreements are designed to avoid this problem by requiring that participants agree to ensure that the core technology and any improvements remain available on the same open terms as the core technology. For example, the BIOS project requires that participants grant back improvements in the core technology and make such improvements freely available to others; the HapMap project requires that users not file for patents for information contained in the data base; and the BioJava license requires that any patent license granted for a version of the original software be consistent with the full freedom of use specified in the license. ${ }^{122}$ Open source biotech projects,

120. See Mark A. Lemley \& David W. O’Brien, Encouraging Software Reuse, 49 STAN. L. REV. 255, 297 (1997) ("Because of the strong rights patent law provides, the standards for obtaining a patent are higher than those for obtaining a copyright or a trade secret.").

121. Compare A. Samuel Oddi, An Uneasier Case for Copyright than for Patent Protection of Computer Programs, 72 NeB. L. REV. 351, 384 (1993) (noting that in order to qualify for patent protection, a computer program must pass requirements for novelty, utility, and non-obviousness, while copyright laws require only minimal originality), and 35 U.S.C. $\S \S 102,103$ (1988) (prescribing that the subject of the patent must be novel and nonobvious), with Feist Publ'ns, Inc. v. Rural Tel. Serv. Co., 499 U.S. 340, 348 (1991) (holding in cases concerning copyrightability of phonebooks that choices as to selection and arrangement, so long as they entail a minimal degree of creativity, are sufficiently original that Congress may protect such compilations through the copyright laws); Alfred Bell \& Co. v. Catalda Fine Arts, Inc., 191 F.2d 99, 102 (2d Cir. 1951) (holding that copyright protection necessitates no large measure of novelty), and Philip Abromats, Nondisclosure of Preexisting Works in Software Copyright Registrations: Inequitable Conduct in Need of a Remedy, 32 JURIMETRICS J. 571, 574 (1992) (noting that in copyright, the originality standard for derivative work is typically expressed as simply requiring more than trivial additions).

122. See, e.g., BIOS Rockefeller Application, supra note 18; HAPMAP 
however, would not necessarily have to adopt this form of licensing. For example, Maurer, Rai, and Sali's Tropical Disease Initiative does not envision that the project would file for patents or restrict others in their ability to file for patents. ${ }^{123}$

Open source biotechnology licenses may implicate the patent misuse prohibition against extending the scope of the patent to cover things beyond what the patent holder invented. For example, when an open source license requires that any improvements must remain freely available to others, the patent holder is using the power of the patent granted on its tool technology to reach an improvement, something not contained in the original patent. Similarly, when the project requires that users give the project a license to any improvements, the patent holder again is using its patent rights on the core technology to affect the disposition of innovations not contained in the original patent.

The open source licensing scheme does not escape patent misuse problems if the improvement is not itself independently patentable. A patent holder can commit patent misuse by reaching beyond its patent to unpatented technology as well as patented technology. ${ }^{124}$ The core question is whether the patent holder has reached beyond what it invented.

An open source approach in which users agree not to file for patents on any information in the database would present an interesting twist. If the information contained in the database is completely in the public domain- that is, not subject to patent protection- the group may avoid the problem of misuse. There can be no patent misuse if the group does not hold patent rights.

If, however, the group does hold patent rights and those patent rights form part of the basis for the contractual arrangement, patent misuse may be implicated. To the extent that a patent holder uses its rights to restrict the disposition of inventions not covered by the grant, the patent holder may be

PROJECT, supra note 1; Open Bioinformatics Foundation, BioJava Project, supra note 60.

123. See Maurer, supra note 1, at 34 .

124. Cf. Morton Salt Co. v. G.S. Suppiger Co., 314 U.S. 488 (1942); 1 HERBERT HOVENKAMP, ET AL., IP AND ANTITRUST: AN ANALYSIS OF ANTITRUST PRINCIPLES APPLIED TO INTELLECTUAL PROPERTY LAW $\S 3.3 \mathrm{~b} 1(\mathrm{~A})$, at 3-12 (Supp. 2003) (describing a classic patent misuse behavior in which a patent holder requires that those who would license the patent also purchase a separate, unpatented product). 
engaging in behavior that extends the scope of the patent grant and thereby may be subject to a claim of misuse.

The open source arrangements that may implicate the patent misuse doctrine fall into two general categories. The first category includes agreements to grant the original patent holder the right to use and sublicense any improvements to the patented technology. The second category includes restrictions on the terms on which the inventor of the improvement may protect its invention. Such restrictions may take the form of dictating the terms upon which the improvement may be licensed or directing that the improvement may not be patented.

In theory, licenses could cover not just improvements in the core research technology, but also products invented using the research technology. For example, one could imagine an open source project grounded on the following principles: "We will provide our research tools for you to develop a product that can improve crop sustainability in underserved nations. If you invent such a product, however, you must make it freely available to others." After all, what good would it do if the project participants subsequently patented their discoveries, making them available only to large agribiotech companies at high prices? Such an arrangement would contemplate that those granted free and open access to the research tools would be required to grant free and open access to the things invented with those tools.

Most open source projects have tried to steer clear of such an expansive licensing arrangement, limiting their reach to improvements made on the core research technology rather than products invented using the technology. Nevertheless, the implications are similar for both. In assigning rights to inventions, the Patent Act does not distinguish between inventions that are improvements on a prior invention and new inventions. ${ }^{125}$ In both approaches, the patent holder is using patent rights to affect the disposition of technology not within

125. See Gerald Sobel, The Antitrust Interface with Patents and Innovation: Acquisition of Patents, Improvement Patents and Grant-Backs, Non-Use, Fraud on the Patent Office, Development of New Products and Joint Research, 53 AnTitrust L.J. 681, 689 (1985); see also Gen. Elec. Co. v. Wabash Appliance Corp., 304 U.S. 364, 368-69 (1938) (noting that most inventions represent improvements on some existing technology); see also Chiron Corp. v. Genentech, Inc. 268 F. Supp. 2d 1148, 1155 (E.D. Cal. 2002) (noting that "[p]atents are and should be granted to later inventors upon unobvious improvements"). 
the patent. Therefore, both approaches suggest that the patent holder is expanding the scope of the patent beyond its grants. The question is whether the courts should consider such an expansion improper.

One might wonder why the issue of patent misuse has not arisen in the context of open source software. Software is eligible for patent protection, and thus, patent software subject to open source licenses could be subject to a charge of patent misuse. ${ }^{126}$

Many of the intellectual property rights issues in open source software have emerged as copyright rather than patent issues. ${ }^{127}$ Although software can receive both copyright and patent protection, copyright protection begins the moment the software is fixed in a tangible medium of expression, while patent protection requires a long and difficult application process. Thus, if inventors of open source software do not patent their works, there can be no charge of patent misuse.

In recent years, however, copyright has developed its own doctrine of misuse. The doctrine is a relatively new addition to the copyright landscape. No circuit court expressly recognized the defense of copyright misuse until 1990 when the Fourth Circuit decided Lasercomb America, Inc. v. Reynolds. ${ }^{128}$ The court in Lasercomb found that a ninety-nine year noncompete clause constituted copyright misuse in part because the clause

126. See Nadan, supra note 66, at 367-68 (noting that even if open source licenses are binding, the copyleft provisions may not be enforceable in light of the intellectual property misuse concepts including patent misuse); see also Lawrence D. Graham \& Richard O. Zerbe, Jr., Economically Efficient Treatment of Computer Software: Reverse Engineering, Protection, and Disclosure, 22 RUTGERS COMPUTER \& TECH. L.J. 61, 93-94 (1996) (describing the test for patentability of software).

127. See e.g., Nadan, supra note 66, at 369-71 (discussing copyright concerns related to the GPL); Shawn W. Potter, Opening Up to Open Source, 6 RICH. J.L. \& TECH. 24, ๆף 56-74 (Spring 2000) (detailing copyright concerns related to open source software), at. http://www.richmond.edu/jolt/v6i5/article3.html.

128. 911 F.2d 970 (4th Cir. 1990); see David Scher, The Viability of the Copyright Misuse Defense, 20 FordhaM URB. L.J. 89, 91 (2000) ("Although the misuse defense was discussed in the context of a copyright action in dictum as early as 1948, the first court to employ the misuse defense to actually render a copyright unenforceable was the Court of Appeals for the Fourth Circuit in 1990.”); G. Gervaise Davise, III, The Rapidly Growing Defense of Copyright Misuse and Efforts to Establish Trademark Misuse, in INTELL. PROP. ANTITRUST 639, 645 (PLI Intellectual Property Course Handbook Series No. G-566, 1999); Aaron Xavier Fellmeth, Copyright Misuse and the Limits of the Intellectual Property Monopoly, 6 J. INTELL. PROP. L. 1, 4 (1998) ("Until 1990, no federal circuit court and only one federal district court accepted the copyright misuse defense ....”). 
would have denied the public the creative abilities of the licensee and its staff for an excessive period of time. ${ }^{129}$

Lasercomb, considered the leading case on copyright misuse, established a broad definition of copyright misuse, similar to the equitable doctrine of unclean hands. ${ }^{130}$ Lasercomb's definition of copyright misuse is generally considered more expansive than the definition of patent misuse, and there have been some efforts to narrow Lasercomb's broad definition. ${ }^{131}$ One might have expected that challenges to the open source licensing structure would include a charge of copyright misuse. 132

The simplest answer is that there have been few cases testing the validity of the licensing restrictions in the open source software movement. ${ }^{133}$ As more cases emerge, open source software licenses may indeed be challenged as patent or copyright misuse.

\section{ANALOGIES TO TRADITIONAL PATENT LICENSING}

As described above, many of the arrangements used in open source biotechnology projects could be characterized as

129. See Lasercomb, 911 F.2d at 978.

130. See Davise, supra note 128, at 645; Ilan Charnelle, The Justification and Scope of the Copyright Misuse Doctrine and its Independence of the Antitrust Laws, 9 UCLA ENT. L. REV. 167, 179 (2002) (noting that copyright defense has its historical roots in the unclean hands defense, not in antitrust); Atari Games Corp. v. Nintendo of Am. Inc., 975 F.2d 832, 846 (Fed. Cir. 1992) ("In the absence of any statutory entitlement to a copyright misuse defense, however, the defense is solely an equitable doctrine. Any party seeking equitable relief must come to the court with 'clean hands'."); see also Alcatel USA, Inc. v. DGI Technologies, Inc., 166 F.3d 772, 792 (5th Cir. 1999) (citing Lasercomb, 911 F.2d at 792).

131. See Davise, supra note 128, at 645; see also Fellmeth, supra note 128, at 27-28 (arguing that in general, the "rule of reason analysis is different when applied to copyright misuse insofar as some courts construe anticompetitive conduct with respect to copyrights more leniently than with respect to patents").

132. See Nadan, supra note 66, at 369 (discussing grantbacks and patent misuse in the context of open source software).

133. See Dennis M. Kennedy, A Primer on Open Source Licensing Legal Issues: Copyright, Copyleft, and Copyfuture, 20 ST. LOUIS U. PUB. L. REV. 345, 368 (2000); $C f$. Nadan, supra note 66, at 368 (noting that the courts have yet to analyze a copyleft provision for misuse). In 2004, one American and one German case have addressed issues related to enforceability of the GPL. See Computer Associates Int'l v. Quest Software, Inc., 333 F. Supp. 2d 688 (N.D. Ill. 2004); GPL Gains Clout in German Legal Case, CNET NEWs, April 22, 2004, available at http://news.com.com/2100-7344_35198117.html?part=business2-cnet. 
attempts to extend the scope of its patent beyond the grant. The proper inquiry under such circumstances should be to examine the effects of the behavior to determine whether such an attempt is impermissible.

Open source biotechnology arrangements can be analogized to three types of arrangements that have appeared in patent licensing outside of the open source arena: field of use restrictions, grantbacks, and reach-throughs. All three have been alleged, under certain circumstances, to constitute misuse. ${ }^{134}$

Precedents in these areas are few, and the logic is frequently unsatisfying. In particular, courts often resolve these cases by simply declaring that a behavior falls inside or outside the patent grant. Thus, questions are resolved not by looking at the extent of the invention and how far the behavior reaches, but by concluding that it seems right to allow a patent holder to engage in a behavior, so the behavior must surely fall within the patent grant. The following section describes the precedents in each of the three areas, exploring analogies to open source licensing.

\section{A. FieLD of Use RestRictions}

A field of use restriction places a limit on what licensees can do with a patented product. Limits could include a restriction on the type of product that a licensee can make with a patented invention. ${ }^{135}$ For example, in Baldwin-Lima

134. See HovenKAMP, ET AL., supra note 124, § 3.3b4, at 3-27 (describing grantbacks); Bayer AG v. Housey Pharmaceuticals, Inc., 228 F. Supp. 2d 467 (D. Del. 2002) (concerning an allegation of patent misuse based on reachthrough royalties); see also Rebecca S. Eisenberg, Technology Transfer and the Genome Project: Problems with Patenting Research Tools, 5 RISK 163, 172 (1994) (describing reach-through royalties); Principles and Guidelines for Recipients of NIH Research Grants and Contracts on Obtaining and Disseminating Biomedical Research Resources: Final Notice, 64 Fed. Reg. 72090, 72091 (Dec. 23, 1999) [hereinafter NIH Guidelines] (describing reachthrough royalties).

135. See Baldwin-Lima-Hamilton Corp. v. Tatnall Measuring Sys. Co., 169 F. Supp. 1, 30 (E.D. Pa. 1958) (finding the restriction outside the patent grant), aff'd per curiam, 268 F.2d 395 (3d Cir. 1959). See also Turner Glass Corp. v. Hartford-Empire Co., 173 F.2d 49, 53 (7th Cir. 1949) (finding no antitrust violation when patentee leased glass-making machine under the condition that it could be used only to make certain types of glassware); Barr Rubber Prod. Co. v. Sun Rubber Co., 277 F. Supp. 484, 506 (S.D.N.Y. 1967) (finding that holder of process patent could license one firm to use the process for making hobby horses while denying this mode of use to other licensees), aff'd 425 F.2d 1114 (2d Cir. 1970). 
Hamilton Corp. v. Tatnall Measuring Systems Co., 136 the patent holder had invented a gauge to test the amount of stress effects on a material. 137 A manufacturer could make expendable gauges that could be used as a tool to test different materials, The gauges also could be manufactured as part of some other machine or apparatus for constant monitoring. 138 The patent holder manufactured gauges for constant monitoring and restricted licensees to making expendable gauges. ${ }^{139}$

Other limits are a restriction on the type of customers to whom a licensee may sell, or a requirement that a licensee restrict the uses that its customers can make of the product. ${ }^{140}$ For example, in General Talking Pictures v. Western Electric Co., ${ }^{141}$ licensees were permitted to sell patented amplifier tubes only to those who manufactured products for private home use but not to those who manufactured equipment for commercial theaters. ${ }^{142}$

In general, courts have allowed field of use restrictions on classes of customers to whom licensees can sell and restrictions on the kinds of objects that the patented process may be used to produce. ${ }^{143}$ At times, however, they have been willing to strike down such agreements as illegal. ${ }^{144}$ The reasoning and results are far from clear and consistent, and there have been no Supreme Court decisions on field of use restrictions since the

136. 169 F. Supp 1, 30 (E.D. Pa.1958).

137. See id. at 28.

138. See id.

139. Id.

140. See Gen. Talking Pictures Co. v. W. Elec. Co., 304 U.S. 175 (1938), aff'd on reh'g, 305 U.S. 124 (1938).

141. 304 U.S. 175 (1938), aff'd on reh'g, 305 U.S. 124 (1938).

142. See Gen. Talking Pictures, 304 U.S. at 180.

143. See United States v. Studiengesellschaft Kohle, 670 F.2d 1122, 1133 (D.C. Cir. 1981); see also 6 CHISUM, supra note 6, § 19.04[3][i], at 507 (describing how lower courts have upheld use and style restrictions).

144. See Studiengesellschaft Kohle, 670 F.2d at 1133. The Studiengesellschaft Kohle court noted the following:

Courts have generally followed General Talking Pictures in holding legal such field-of-use restraints as a restriction on classes of customers to which licensees could sell and a restriction on the kinds of objects on which the process could be used. But courts have occasionally distinguished General Talking Pictures and held the restraint illegal where they perceived that the field-of-use restriction was being used to extend the patent into areas not protected by the patent monopoly, such as a requirement that a patented strain gauge Id. only be sold with the licensee's machines. 
1938 decision in General Talking Pictures ${ }^{145}$ Commenting on General Talking Pictures, the leading patent treatise notes that the Court "seemed to uphold the legality of restricted use conditions simply because they reflected a venerable practice that had gone unquestioned for many years."146 In addition, the decision has been clouded by later Supreme Court cases that could be read to implicitly overrule it. 147

The confusion can be traced to a clash between the notion that patent holders should be permitted to organize their monopoly in an efficient manner ${ }^{148}$ and the first sale doctrine, which holds that patent holders cannot control the use of a patented item once it has been placed in the channels of commerce. According to the first sale doctrine, the first authorized sale of a patented article frees it from the patent monopoly. ${ }^{149}$ Patent holders who try to restrain the use of the patented article after the first authorized sale may be exceeding the scope of the patent and are thereby subject to a charge of misuse. ${ }^{150}$

The first sale doctrine traces its heritage to real property doctrines as well as intellectual property doctrines. It is grounded in theories of free alienability of chattel as well as the view that individuals expect to be able to use the items they purchase in any manner. ${ }^{151}$

In 1938, the Supreme Court faced a direct clash of the two

145. In the Supreme Court case of Automatic Radio Manufacturing Co. $v$. Hazeltine Research, Inc., 339 U.S. 827 (1950), the parties challenged a provision requiring that a licensee attach a notice to a product restricting its use to private, educational, and non-commercial uses. See id. at 834-35. The Supreme Court declined to address the question, however, ruling that the issue was not properly before the Court. See id. at 835-36.

146. 6 CHISUM, supra note $6, \S 19.04[3][\mathrm{i}]$, at 507.

147. See id. § 19.04[3][i], at 510 (discussing General Talking Pictures and its continued viability in the lower courts even though later Supreme Court cases such as United States v. Univis Lens, 316 U.S. 241 (1942), have implicitly overruled portions of the case by reaffirming the first sale doctrine in the area of price-fixing).

148. See Ciba-Geigy Corp. v. Bolar Pharm. Co., 212 U.S.P.Q. (BNA) 712, 713 (E.D.N.Y. 1981) ("Ciba's licensing practices may, as a practical matter, have the effect of restricting the market ... . This effect, however, is a direct result of the HCT monopoly created by the 645 patent.").

149. See 6 CHISUM, supra note $6, \S 19.04[3][\mathrm{h}]$, at 502.

150. See id. §19.04[3][i], at 505.

151. See Cotton-Tie Co. v. Simmons, 106 U.S. 89 (1882); Patent Use Restrictions, 75 HARV. L. REV. 602, 606 (describing the first sale doctrine as applied in American Cotton-Tie and noting that the Court spoke in terms of property law). 
issues in the case of General Talking Pictures 152 In General Talking Pictures, the patent holder held a patent on amplifier tubes. ${ }^{153}$ Licensees were given the right to make the tubes, but were only allowed to sell them for use in equipment designed for homes. They were not given the right to sell them for use in commercial movie house equipment.154 The Supreme Court upheld the restrictions in a decision which it subsequently reaffirmed with an additional opinion on rehearing. ${ }^{155}$

The facts presented two potential types of restrictions on use after sale. First, the patent holder arguably was restraining the licensee's use after proper purchase by telling licensees that they could sell the tubes only to certain customers. The Supreme Court, however, declared that the patent grant embraces this type of restriction with no discussion beyond the fact that the practice is an old one that has never been questioned. ${ }^{156}$

Second, the licensing arrangement could be described as limiting what the secondary buyers of the tubes could do after purchasing them from the licensed manufacturer. In particular, secondary purchasers were effectively restricted to using the particular tubes in home rather than commercial equipment. Such a limit would restrict what a purchaser could do once an item has been purchased in the ordinary channels of commerce, in contravention of the first sale doctrine.

The Court's language suggested that restrictions on what the secondary purchaser does might have been problematic, but that such was not the issue in this case. From the Court's perspective, the manufactured item had not passed appropriately into the stream of commerce because its manufacture was not permitted in the first place. 157 The court

152. Gen. Talking Pictures Co. v. W. Elec. Co., 304 U.S. 175 (1938), aff'd on reh'g, 305 U.S. 124 (1938).

153. See Gen. Talking Pictures, 304 U.S. at 176.

154. See id. at 180.

155. See Gen. Talking Pictures, 305 U.S. at 125-26. The rehearing opinion appears to be crafted to avoid the question of whether later purchasers can be restricted by a notice affixed to the product. See id. at 127 ("Nor have we occasions to consider the effect of a 'licensee's notice' which purports to restrict the use of articles lawfully sold.”).

156. See id. at 127. The original decision offered no more discussion than the rehearing. See Gen. Talking Pictures, 304 U.S. at 181 (stating simply that "[t]here is no attempt on the part of the patent owner to extend the scope of the monopoly beyond that contemplated by the patent statute").

157. See Gen. Talking Pictures, 304 U.S. at 180-81; Gen. Talking Pictures, 305 U.S. at 127. 
reasoned that because the original licensee sold the product outside the scope of the license, the effect was the same as if no license whatsoever had been granted to the secondary buyer. ${ }^{158}$ Questions about restrictions on the secondary buyer simply didn't apply because the secondary buyer had no right to the product at all.

In short, the court avoided application of the first sale doctrine and held that a patent holder could restrict licensees to manufacturing for a particular field of use. Little logic, however, was provided for the decision. In addition, although lower courts generally have followed General Talking Pictures, some scholars have questioned its vitality given later Supreme Court cases that implicitly overrule parts of the case by reaffirming the first sale doctrine in the context of pricefixing. 159

One lower court, however, distinguished General Talking Pictures by finding a distinction between a patented machine and patented components. ${ }^{160}$ In United States $v$. Consolidated Car-Heating, ${ }^{161}$ the patent holder had invented a metal alloy. ${ }^{162}$ The patent holder prevented licensees from using the alloy to manufacture anything other than dental restorations, such as crowns and dentures. ${ }^{163}$ The court found patent misuse, essentially concluding that while a patent holder may restrict the use its product is sold for under General Talking Pictures, a patent holder cannot make that restriction when the product will be used as a component in manufacturing something else. ${ }^{164}$ Again, the court provided little explanation for the decision.

Although the distinction may have been an attempt to salvage the first sale doctrine, it makes little sense and does not fit easily within the facts of the two cases. In General

158. See Gen. Talking Pictures, 305 U.S. at 127.

159. See 6 CHISUM, supra note $6, \S 19.04$ [3][i], at 510 (questioning the viability of General Talking Pictures in light of cases such as United States v. Univis Lens, 316 U.S. 241 (1942)).

160. See United States v. Consol. Car-Heating Co., 87 U.S.P.Q. (BNA) 20, 21-23 (S.D.N.Y. 1950); 6 CHISUM. supra note 6, § 19.04[3][i], at 511 (describing United States v. Consolidated Car-Heating and noting that to avoid General Talking Pictures, the court drew a rather fine distinction between patented machines and patented components and materials).

161. Consol. Car-Heating Co., 87 U.S.P.Q.(BNA) at 20.

162. Id. at 21 .

163. Id. at $22-23$.

164. See id. at 23 . 
Talking Pictures, the licensee sold tubes for inclusion in equipment. From a broad perspective, this could be considered selling a component to be used in furthering manufacturing.

In 2004, the Federal Circuit waded into the question of field of use restrictions in the case of Monsanto $v$. McFarling. ${ }^{165}$ The Monsanto case concerned Monsanto's patented soybeans seeds and the company's single use restriction. ${ }^{166}$ Monsanto's soybean seeds have been modified by inserting a gene sequence that makes the resulting plants immune from Monsanto's powerful Roundup herbicide. 167 Monsanto requires that seed companies who produce Monsanto's seeds must execute license agreements with farmers in which the farmers agree not to replant any seeds harvested from the soybean plants. ${ }^{168}$ In other words, the farmers may purchase seeds, use the seeds to grow soybean plants, and sell the seeds from the soybean plants for food, but not use the seeds from the soybean plants for replanting. Monsanto brought an infringement suit against a farmer who saved 1,500 bushels of soybean seeds from his crop, enough to plant 1,500 acres the following year. ${ }^{169}$

Although the Federal Circuit upheld the single use restriction, it found that the restriction could not be characterized as a valid field of use restriction. ${ }^{170}$ The court reasoned that the restriction did not place limitations on the use of the product purchased under the patent, which could have been valid. ${ }^{171}$ Rather, the agreement placed restrictions on the use of the goods made with the licensed product, which extended beyond the patent grant. ${ }^{72}$ In other words, Monsanto sold first generation seeds that could be used to grow soybean plants that make other seeds. Placing restrictions on what could be done with the second generation seeds that had been produced by the patented product would not be legitimate.

Although the restriction did not constitute a legitimate field of use limitation, the court reasoned that the facts of the case presented a unique set of circumstances that justified the restrictions. Given that the second-generation seeds contain

165. 363 F.3d 1336, 1339 (Fed. Cir. 2004).

166. See id.

167. See id. at 1338.

168. Id. at 1339 .

169. See id. at 1339-40.

170. See id. at 1342-43.

171. See Monsanto v. McFarling, 363 F.3d 1336, 1342-43 (Fed. Cir. 2004).

172. See id. 
Monsanto's patented genetic sequence, the court found that Monsanto held rights in the second-generation seeds as well.173

Thus, given that we must presume that Monsanto's ' 435 patent reads on the first-generation seeds, it also reads on the second-generation seeds. Because the ' 435 patent would read on all generations of soybeans produced, we hold that the restrictions in the Technology Agreement prohibiting the replanting of the second generation of ROUNDUP READY ${ }^{\circledR}$ soybeans do not extend Monsanto's rights under the patent statute. ${ }^{174}$

The court left open, however, what it saw as the more difficult question of restrictions on the use of goods that are made by the patented technology but do not incorporate it. 175

Monsanto's facts do present an interesting variation in that most technology does not replicate itself in the way that living organisms do. Technology generally is used as a tool to make something else or as a component in making something else but not to make a new version of itself, except perhaps in the case of certain software applications in which code replicates itself. In the Monsanto case, one can think of the creation of the second generation seeds as the creation of a new product. Perhaps restrictions can be applied to creation of a new product, even if not to later sales.

Nevertheless, the facts of Monsanto can be analogized to other, more common cases. The second generation seeds contained Monsanto's patented genetic sequence in the same way that any time a patented product serves as a component; the second product will contain the first. For example, the dentures mentioned in Consolidated Car-Heating contained the patented dental alloy. The court's decision, therefore, could suggest that any restriction on downstream products that contain the patented product as a component will be permissible, regardless of the first sale doctrine, because the patent holder's rights on making, using, and selling its product would be implicated by the formation of a new product that contains a patented element. Such an approach would significantly weaken the first sale doctrine. ${ }^{176}$

173. See id. at 1343 .

174. Id.

175. See id. ("Our case law has not addressed in general terms the status of such restrictions placed on goods made by, yet not incorporating, the licensed good under the patent misuse doctrine. However, the Technology Agreement presents a unique set of facts ....”).

176. The Monsanto opinion follows in the footsteps of an earlier Federal Circuit decision that substantially weakens the first sale doctrine. 
Thus, Monsanto echoes the distinction suggested in Consolidated Car-Heating but with the opposite result. Monsanto would allow restrictions on downstream purchasers and producers if the downstream products contain some component that is patented. The court leaves open the question of downstream products made with the patented technology but not containing it.

One could argue that open source licenses are analogous to field of use agreements. An open source license restricts the use of the patented invention to a particular market, which is the open source market. From this perspective, the patent holder requires, for example, that its patented tool can only be used to manufacture one type of product, and that type of product is open source. Similarly, the patent holder requires that its invention may only be used as a component of one type of product. Again, that type of product would be an open source product.

Under a similar analysis, one could describe open source agreements as limiting the type of customer to whom a licensee can sell. That customer would be one who operates within an open source environment. As a variant of this, one could analyze the agreement as requiring licensees to impose restrictions on the types of uses customers can make of the products made with the patented technology.

If the Monsanto approach were applied to open source biotechnology, licensing restrictions relating to products that contain the patented technology could escape the first sale doctrine's limitation on field of use restrictions. For example, requirements that downstream versions of the software remain available on open terms would be acceptable given that the original software is a component of the downstream product. ${ }^{177}$ The question of whether restrictions on goods made with the open source tool but not incorporating the tool would be acceptable remains unresolved after Monsanto.

In summary, field of use restrictions are frequently upheld,

Mallinckrodt, Inc. v. Medipart, Inc., 976 F.2d 700, 708 (Fed. Cir. 1992).

177. Some have suggested that distinctions among different field of use restrictions are irrelevant, although they do not necessarily agree on the results of eliminating those distinctions. Compare Patent Use Restrictions, supra note 151 (arguing for greater scrutiny of all field of use restrictions on the grounds that they are basically anticompetitive), with Mallinckrodt, 976 F.2d at 705 (finding the distinction between restricting the use of first purchasers and second purchasers to be formalistic line-drawing in a case in which the licensing restrictions were upheld). 
although the cases lack a unifying logic. Courts tend to rely on artificial distinctions between field of use restrictions that fall within the grant of the patent and those that fall outside the grant. As the first sale doctrine fades in Federal Circuit jurisprudence, the legality of a field of use restriction for a patented technology should focus more strongly on the general test for patent misuse, examining the effects of the behavior. The Federal Circuit may have had a similar approach in mind in Mallinckrodt Inc. $v$. Mediapart ${ }^{178}$ when it suggested that a first sale doctrine issue could be cast in terms of general patent misuse inquiry which would then be tested either as a per se violation or under the rule of reason. ${ }^{179}$ Such an approach could mark the death knell for the first use doctrine, although lessons learned from the doctrine could be addressed in the context of the general patent misuse test. The question of whether an open source license analogized to a field of use restriction is permissible would then be tested either by asking whether the effects of the behavior are inconsistent with patent policy or by following the Federal Circuit's current approach of testing whether the effects of the behavior are inconsistent with the antitrust rule of reason.

\section{B. GRANTBACKS}

Some open source licensing arrangements can be analogized to grantback provisions. Grantback clauses require the licensee to give the patent holder rights in products that the licensee develops. ${ }^{180}$ Grantbacks may include only improvements to technology that falls within the scope of the original patent claims or may extend to all inventions within the general subject matter of the patent. ${ }^{181}$

Some grantbacks are exclusive, thereby giving the patent holder sole rights to any further invention. 182 The licensee who invented the improvement may or may not have permission to use the improvement as well, and that permission may or may

178. 976 F.2d 700, 708 (Fed. Cir. 1992).

179. See id. at 706-09.

180. See 6 CHISUM, supra note 6, § 19.04[3][j]; HovENKAMP, ET AL., supra note $124, \S 3.3 \mathrm{~b} 4$, at $3-27$.

181. See 6 CHISUM, supra note 6, § 19.04[3][j], at 520.

182. Some exclusive grantbacks allow the second inventor to retain the rights to use the improvement. See HOVEnKAMP, ET AL., supra note 124, § $3.3 \mathrm{~b} 4$, at 3-28-29 (describing different forms of exclusivity in grantback agreements). 
not require additional royalties. ${ }^{183}$ In contrast, some grantbacks are nonexclusive licenses, in which the original patent holder presumably will be one of many licensees who have permission to use the improvement. ${ }^{184}$ Again, the licensee who invented the improvement may or may not be required to pay additional royalties to use the invention.

Grantbacks in more limited form generally have been upheld against claims of misuse. 185 These provisions have been structured primarily in two ways. First, the licensee grants the original patent holder a royalty-free license to use the improvement. In the alternative, the licensee assigns the rights to the improvement back to the original patent holder but reserves right to use the improvements at no additional royalty. ${ }^{186}$

For example, in 1947, the Supreme Court considered a patent misuse challenge to a clause requiring that a licensee assign all improvements back to the patent holder, but granting the licensee the right to use the improvements. ${ }^{187}$ In this case, Transparent-Wrap Machine Corp. v. Stokes \& Smith Co., ${ }^{188}$ the court held that the agreement extended beyond the scope of the basic term of the patent but declined to find misuse. ${ }^{189}$ The court rejected the argument that the clause reduced the downstream inventor's incentive to innovate, reasoning that the licensee's right to use the invention without additional royalty created sufficient incentive for innovation. ${ }^{190}$ The court did note, however, that grantbacks could not be used

183. See Shelia J. McCartney, Licensing Alternatives to Limit Antitrust and Misuse Exposure, 7 J. PROPRIETARY RTS. 10, 13 (1995); see also TransparentWrap Mach. Corp. v. Stokes \& Smith Co., 329 U.S. 637, 646 (1947) (holding that the licensee has the right to use the improvement at no additional royalty).

184. See HovenKAMP, ET AL., supra note 124, § $3.3 \mathrm{~b} 4$, at $3-28-29$ (describing different forms of exclusivity in grantback agreements).

185. See, e.g., Duplan Corp. v. Deering Milliken, Inc., 444 F.Supp. 648, 699700, (D.S.C. 1977), aff'd in part and rev'd in part, 594 F.2d 979 (4th Cir. 1979); see also 6 CHISUM, supra note $6, \S 19.04$ [3][j], at 525-26 (noting that limited forms of grantbacks have been held not to constitute misuse); McCartney, supra note 183, at 14 (1995) (concluding that although more limited forms of grantbacks are unlikely to constitute misuse, some courts have found misuse where the scope of the grantback is broader than the scope of the original license).

186. See 6 CHISUM, supra note $6, \S 19.01[3][j]$.

187. See Transparent-Wrap, 329 U.S. at 637.

188. 329 U.S. 637, 646 (1947).

189. Transparent-Wrap, 329 U.S. at 645-46.

190. Id. at 646 . 
to suppress competition in violation of the antitrust laws. 191

Subsequent to Transparent-Wrap, one lower court has suggested that in determining whether a grantback clause constitutes misuse, one should examine whether the clause adversely affects the licensee's incentive to engage in research and development. ${ }^{192}$ In examining a misuse claim, the district court in International Nickel Co. v. Ford Motor Co. ${ }^{193}$ noted that grantback provisions that "tend to stifle research are antagonistic to the underlying policies of the patent laws." 194

In applying this test, however, the International Nickel court suggested that the licensee must provide specific evidence that the clause actually stifled innovation, rather than merely showing that the terms have the potential to stifle innovation. For example, the court rejected the claim of misuse on the grounds that considerable research had been conducted by licensees. As a result, the court believed that "any claim that absent the agreement, there would have been greater research was mere conjecture."195

Similarly, in Hull $v$. Brunswick, ${ }^{196}$ the Tenth Circuit upheld a requirement that a licensee pay royalties on its improvements. ${ }^{197}$ Given that no royalties were ever collected on improvements, the court dismissed as merely hypothetical the charge that the provision inhibited innovation. ${ }^{198}$ The court noted in particular that the licensee never established any instances in which innovation was actually inhibited. 199

If potential impact on innovation were relevant, one would have expected the Hull court to consider the deterrent effect of the clause on the decision to innovate. At the very least, in the first instance of an innovation, the innovator presumably would not know that the clause would not be enforced. Even after the patent holder has neglected to collect royalties on improvements, a potential innovator still faces the risk that if

191. See id. at 646-47. Several lower court decisions in antitrust suits have applied Transparent-Wrap to condemn grantbacks used to suppress competition. See 6 CHISUM, supra note 6, § 19.04[3][j], at 520-26.

192. See Int'l Nickel v. Ford Motor Co., 166 F.Supp. 551, 565 (S.D.N.Y. 1958); Sobel, supra note 125 , at 690-91.

193. 166 F. Supp. 551 (S.D.N.Y. 1958).

194. International Nickel, 166 F. Supp. at 565.

195. Id. at 566 .

196. 704 F.2d 1195 (10th Cir. 1983).

197. Hull v. Brunswick Corp., 704 F.2d 1195, 1202 (10th Cir. 1983).

198. Id.

199. Id. 
an improvement were sufficiently substantial, the patent holder might be moved to enforce its right to royalties, a risk that at least has the potential to affect the decision to innovate. Despite leniency on the issue of actual verses potential incentive to innovate, some courts and commentators have questioned the validity of more expansive grantbacks. For example, one court held in 1977 that a grantback constitutes misuse when the licensee is required to grant back improvements related to technology beyond the original innovation. 200 The court described the patented innovation as relating to a mechanism for arresting the twist of a particular textile within a heating medium. ${ }^{201}$ A licensing provision requiring that licensees grant back improvements related to any technology, not just that related to the twisting within a heating mechanism, reached too broadly and constituted patent misuse. 202

Other authorities have suggested that grantbacks may be problematic if they are exclusive rather than nonexclusive. ${ }^{203}$ While nonexclusive grantbacks allow the market for the improvement to thrive, exclusive grantbacks are more likely to restrict competition relating to the improvement. ${ }^{204}$

Grantback provisions in open source biotechnology may be structured as a nonexclusive grant of rights on improvements in the core technology back to the open source project.205 This form of grantback follows the outlines of the grantbacks that

200. See Duplan Corp. v. Deering Milliken, Inc., 444 F. Supp. 648, 699-700 (D.S.C. 1977), aff'd in part and rev'd in part, 549 F.2d 979 (4th Cir. 1979); see also Transitron Elec. Corp. v. Hughes Aircraft Co., 487 F. Supp. 885, 893, 904 (D. Mass. 1980) (describing overbroad grantbacks as classic patent misuse and citing Transparent-Wrap for the proposition that a license provision requiring that the licensee grant back all its own patents to the licensor might constitute patent misuse), aff'd 649 F.2d 871 (1st Cir. 1981); Sobel, supra note 125, at 690-91.

201. See Duplan, 444 F. Supp. at 699-700.

202. See id. at 700 .

203. See HovenKAMP, ET AL., supra note 124 , $\S 3.3 \mathrm{~b} 4$, at 3-27-28; U.S. DEP'T OF JUSTICE AND FED. TRADE COMM'N, ANTITRUST GUIDELINES FOR THE LICENSING OF INTELLECTUAL PROPERTY 5.6 (1995) [hereinafter FTC/DOJ GUIDELINES]; NIH Guidelines, supra note 134.

204. See HovENKAMP, JANIS, \& LEMLEY, supra note 124 , § 3.3b4, at A3-28; FTC/DOJ Guidelines, supra note 203; NIH Guidelines, supra note 134.

205. See, e.g., Janet Hope, Open Source Biotechnology: My View on Open Source and Pharmaceutical Companies, at http://rsss.anu.edu.au/ janeth/OSBiotech.html; (last visited July 14, 2004); see also Salleh, supra note 1, (noting that licensees will agree to share improvements in the core technology). 
generally have been approved by courts and agencies. ${ }^{206}$ Open source provisions that require an exclusive grant of rights back to the group or that extend to products invented using the patented technology would be more troubling.

Open source licensing, however, may involve considerations beyond those of ordinary grantbacks. Under ordinary circumstances, nonexclusive grantbacks are acceptable in part because although the improver must grant rights to the original patent holder, the improver is also free to grant rights to others. This freedom gives the improver room to capitalize on the invention, at least with customers other than the original patent holder. The ability to capitalize in this matter may allay concerns that the grantback could inhibit the licensee's incentive to create improvements. The licensee is always free to garner a return from customers other than the original patent holder.

Such is not the case with open source licensing. In much open source licensing, the licensee is required not only to grant nonexclusive rights to the open source group, but also to license others on the same open terms as the original license. Thus, the improver may be unable to garner a return in any market. Who would pay the improver when the improvement is available for free from the open source project? This provision could, in theory, effect incentives to improve the core technology. As with field of use restrictions, however, the relevant analysis for any particular form of grantback would turn on whether the effects of the behavior are inconsistent with patent policy or the antitrust rule of reason.

\section{REACH-Through Provisions}

Reach-through provisions have appeared most frequently in the context of reach-through royalties on biotechnology research tools. ${ }^{207}$ Under a reach-through royalty, payments for

206. See FTC/DOJ GUIDELINES, supra note 203, § 5.6; see 6 CHISUM, supra note $6, \S 19.04[3][j]$, at 525-26 (noting that courts generally have upheld limited forms of grantbacks).

207. See, e.g., Eisenberg, supra note 134, at 172 (describing reach-through royalties on sales of products that are developed in part through use of biotech research tools); see Bayer AG v. Housey Pharm., Inc., 228 F. Supp. 2d 467, 471 (D. Del. 2002) (upholding a reach-through royalty on biotech research despite allegations of patent misuse); see also NIH Guidelines, supra note 134, at 72,093 (expressing disapproval of reach-through royalties on biotech research tools); see also John H. Barton, Research-Tool Patents: Issues for Health in the Developing World, 80 BULL. WORLD HEALTH ORG. 121 (2002) (describing ways 
use of a patented technology are measured in relation to products created through a process involving the technology. ${ }^{208}$ For example, if the patented technology is a tool for isolating a particular protein, a reach-through royalty might be structured such that the licensee pays royalties based on a percentage of sales from any drugs later developed to interact with the protein. With a reach-through royalty, one could argue that the patent holder is using rights granted in one technology to garner a return on an invention not covered in the patent grant. 209

A similar issue arises with reach-through claims. With reach-through claims, a broad enabling technology is patented with claims drafted to cover things produced using that technology. The Federal Circuit recently rejected claims drafted as reach-throughs. ${ }^{210}$

The legal status of reach-through royalties is unclear. Only one case has addressed whether a reach-through royalty constitutes patent misuse, and the court found no misuse. ${ }^{211}$ In contrast, the National Institutes of Health guidelines strongly discourage the use of reach-through royalties. ${ }^{212}$ In addition, scholars have argued that reach-through royalties are detrimental to the patent system because of the royalty stacking effects and the tendency to discourage downstream innovation. ${ }^{213}$ Again, to the extent that open source licenses are analyzed as reach-throughs, the relevant analysis will be whether the effects of the behavior are inconsistent with patent policy or the antitrust rule of reason, depending on the rule

in which purchasers have tried to avoid reach-through royalties on research tools), available at http://www.scielosp.org/scielo.php?script=sci_arttext \&pid=S0042-96862002000200007\&lng=en\&nrm=iso\&tlng=en.

208. See Michael A. Heller \& Rebecca S. Eisenberg, Can Patents Deter Innovation? The Anticommons in Biomedical Research, 280 SCIENCE 698, 699 (1998).

209. See Feldman, supra note 7 , at 439-49.

210. See Univ. of Rochester v. G.D. Searle \& Co., Inc., 249 F. Supp. 2d 216, 235 (W.D.N.Y. 2003); see also Anne Y. Brody, Rochester v. Searle: Complying with the Written Description and Enablement Requirements in Early-Stage Drug Discovery, 22 BIOTECH. L. REPORT 472 (2003).

211. See Bayer, 228 F. Supp. $2 d 467$.

212. See NIH Guidelines, supra note 134, at 72,093.

213. See Barton, supra note 207, at 121; Eisenberg, supra note 134, at 172; Feldman, supra note 7, at 442; Heller \& Eisenberg, supra note 208, at 699; see also Gene Patents and Other Genomic Inventions: Hearing Before the Subcomm. On Courts and Intellectual Prop., House Comm. on the Judiciary, 106th Cong. 85 (2000) (statement of Dr. Harold Varmus, President and Chief Executive Officer, Memorial Sloan-Kettering Cancer Center). 
applied.

\section{ARE THE EFFECTS OF OPEN SOURCE BIOTECH LICENSING CONSISTENT WITH PATENT POLICY?}

Many open source biotechnology licenses appear to extend the scope of the patent to inventions beyond what is described in the patent grant. The question is whether the expansion is impermissible. One approach to testing whether open source agreements are permissible is to examine whether the effects of open source agreements are consistent with patent policy. ${ }^{214}$

The primary goal of the patent system is to promote the progress of science for the benefit of the public. ${ }^{215}$ The system is intended to foster the creation and disclosure of new inventions, which will provide long-term benefits for society. ${ }^{216}$ In this context, the Supreme Court has noted "[t]he primary purpose of our patent system is not reward of the individual but the advancement of the arts and sciences. Its inducement is directed to disclosure of advances in knowledge which will be beneficial to society; it is not a certificate of merit, but an

214. See Blonder-Tongue Lab., Inc. v. Univ. of Ill. Found., 402 U.S. 313, 343 (1971) (noting that the Court has condemned attempts to broaden the physical or temporal scope of the patent monopoly), remanded on other grounds to 334 F. Supp. 47 (N.D. Ill. 1971), aff'd 465 F.2d 380 (7th Cir. 1972), cert. denied 409 U.S. 1061 (1972); 6 CHISUM, supra note 6, at $\S 19.04$ (discussing patent misuse).

215. See U.S. ConsT. art. I, § 8, cl. 8; Kewanee Oil v. Bicron Corp., 416 U.S. 470, 480 (1974) (explaining that the patent laws carry out the Constitutional mandate to "promote this progress by offering a right of exclusion for a limited period as an incentive to inventors to risk the often enormous costs in terms of time, research, and development"); Graham v. John Deere Co., 383 U.S. 1, 8-9 (1965) (citing Thomas Jefferson for the proposition that the patent monopoly was not designed to secure to the inventor his natural rights to his discoveries but rather as a reward or inducement to bring forth new discoveries); Sinclair \& Carroll Co., Inc. v. Interchemical Corp., 325 U.S. 327, 330-31 (1945) (stating primary purpose of the patent system is to induce advancements in the arts and science); cf. Mazer v. Stein, 347 U.S. 201, 219 (1954) ("[C]opyright law, like the patent statutes, makes reward to the owner a secondary consideration.") (internal quotation marks omitted), reh'g denied, 347 U.S. 949. But see Eldred v. Ashcroft, 538 U.S. 186, 212 n.18 (2003) (questioning dissent's analysis of the notion that reward of authors is a secondary consideration in copyright law and arguing that end goals of the reward of authors and progress of science are not mutually exclusive in that copyright law serves public ends by providing individuals with an incentive to pursue private ones), reh'g denied, 538 U.S. 916 (2003).

216. See Kewanee Oil, 416 U.S. at 480; Graham, 383 U.S. at 8-9; Sinclair \& Carroll Co., 325 U.S. at 331. 
incentive to disclosure." 217

To accomplish this ultimate goal, we grant patent holders limited rights to exclude others from their invention, while recognizing that such rights may create negative effects. ${ }^{218}$ Nevertheless, the current patent system strikes a balance between the positive incentive effects that will redound to the public benefit and any negative effects that the creation of patent rights may produce.219 Positive and negative effects should be evaluated on a system-wide basis, not according to whether a particular arrangement would benefit the parties to that arrangement. 220

Within this context, open source licenses can be viewed as consistent with patent policy. A patent delays the point at which knowledge enters the public domain until the end of the patent term. By ensuring that improvements and other developments are immediately available, open source accelerates the moment of dedication to public use. An acceleration of the moment at which knowledge is brought to the public domain is consistent with the goals of patent policy, which are focused on obtaining new inventions for the public benefit. $^{221}$

On the other hand, one could argue that open source clashes with the goals of the patent system by lowering the available reward for downstream inventions. Although the primary goal of the patent system is bringing forth knowledge for the benefit of the public, the vehicle to accomplish that goal is allocation of reward to inventors. If open source were to lower overall incentives to downstream inventors, it could

217. Sinclair \& Carroll Co., 325 U.S. at 330-31 (internal footnote omitted).

218. See Atl. Works v. Brady, 107 U.S. 192, 200 (1882) (discussing the costs of granting patent monopolies and the importance of reserving patents only for those inventors who make discoveries or inventions that are sufficiently substantial); Robert P. Merges \& Richard R. Nelson, On the Complex Economics of Patent Scope, 90 COLUM. L. REV. 839, 868 (1990) (discussing Kaplow, Gilbert, and Shapiro's works on the subject).

219. For a more comprehensive analysis of the theory of patent rights and the balance of positive and negative effects, see Feldman, supra note 7, at 43138.

220. See id. at 443, 448.

221. See, e.g., Kewanee Oil, 416 U.S. at 480 (patent laws create incentives for inventors to engage in productive activities which "will have a positive effect on society through the introduction of new products"); Graham, 383 U.S. at 8-9 (patent monopoly induces inventors to bring forth new discoveries); Sinclair \& Carroll Co., 325 U.S. at 330-31 (patent system is designed to induce advancements, which will be beneficial for society). 
reduce the amount of downstream invention in the long term, which would be inconsistent with patent policy.

Such an analysis, however, fails on several levels. First, it fails to properly measure the incentives offered in the open source system. In the normal vision of the patent system, a patent holder's incentive and reward are measured by the level of economic return. In an open source system, participants also are motivated by non-economic factors such as a desire for prestige and a desire to satisfy altruistic goals, including serving those less fortunate and participating in the advancement of science. An analysis that looks solely at traditional economic rewards fails to capture the full dynamic of the open source system.

If rewards such as altruism and prestige are sufficient motivations for invention, however, one might ask why a patent system is necessary in the first place. Wouldn't the lure of prestige, helping those less fortunate, and contributing to the greater growth of science lure people into making inventions such that there would have been no need for a patent system? Without a patent system and an open source system, however, the promise of non-economic rewards might be illusory. It could be overshadowed by the ability of others to usurp inventions through commercial exploitation. For example, I could invent an application that increases crop durability, and dedicate my invention to the public benefit. The dedication would be fruitless, however, if others could improve or adapt the invention and make those advancements proprietary. In this way, downstream inventors reap economic rewards that are in part derived from my inventions. The mechanism of securing rights to produce those economic rewards interferes with the dedication of my invention to the public good, which would produce my altruistic reward. It is only the imposition of open source agreements that preserves the integrity of the altruistic reward, and it is only the patent system that permits the development of open source.

Regarding the concern that open source may reduce innovation, one could also argue that open source taps potential innovation that the traditional free market cannot reach. For example, those who participate in open source projects, software or biotechnology, may do so in free time or in the type of intermittent segments that do not lend themselves well to commercial enterprise. From the perspective of the effects on the overall patent system, one should consider that open source 
may harness untapped energy, thereby increasing society's overall innovative potential.

In addition, rather than simply arguing that open source may reduce patent rewards, one should look at the overall impact of open source to determine whether it undermines the balances implicit in the patent system. In other words, one must consider the effects of open source on the harms of the current patent system as well as the benefits of the current patent system.

Although open source biotechnology may reduce downstream rewards if only traditional economic rewards are measured, open source also reduces the harms side of the equation. Open source cuts through patent thickets that threaten to choke off innovation. In addition, open source does not generate the kinds of monopolistic effects that the patent system normally produces. Ordinarily, we tolerate the fact that patent holders who have market power will increase price and reduce supply during the patent term. ${ }^{222}$ This is part of the necessary harms of the patent system. In contrast, given that open source products are openly available for use, they would not produce the same level of restriction of supply as one would expect in the patent system.

There may, of course, be some restriction of supply with open source as compared to a system with no intellectual property rights. Use is restricted to those who agree to follow the rules of the open source system, which may be a smaller pool than those who would use the product if it were in the public domain. Nevertheless, as a general matter, one could expect open source to result in far greater usage than under a traditional patent licensing arrangement.

There may be exceptions, however, to the rule that traditional patent licensing will substantially restrict supply. For example, a patent holder could choose to make its invention broadly available on nominal terms. The Cohen/Boyer patent for recombinant technology was reportedly licensed in broad, nonexclusive agreements requiring relatively low royalty

222. See Arrow, supra note 14, at 617 (noting that patent rights produce underutilization of information); Kesan \& Banik, supra note 13, at 23-24 (noting that patents "impose social costs such as reduced levels of competition or wasteful design-around efforts by competitors" but also create an incentive to invest in research and development that leads to innovation); see generally Merges \& Nelson, supra note 218 (discussing the "complex economics of patent scope"). 
payments.223 That invention and its licensing methods are credited with spawning the development of the modern biotechnology industry. ${ }^{224}$ The Cohen/Boyer patent, therefore, demonstrates that licensing behavior that does not greatly restrict supply is possible under traditional patent licensing, even if it may be rare.

The Cohen/Boyer experience also provides insight into the interplay between broad access and the patent system. First, it serves as a reminder that broad access to technology can be highly beneficial for encouraging innovation. In addition, the Cohen/Boyer experience suggests that broad, cheap access is not necessarily inconsistent with the patent system.

In short, although an open source system may reduce some downstream economic rewards, an open source system increases non-economic rewards and incentives. It may also increase the level of invention exploiting untapped innovative energy. Open source licensing also reduces the harms of the current patent system by reducing patent thickets and avoiding the short-term restriction of supply that one would expect under traditional patent licensing. The ultimate effect of open source licensing is to increase the supply of innovation and the speed at which such innovation is available for the public benefit. These effects advance the goals of the patent system.

\section{ARE THE EFFECTS OF OPEN SOURCE BIOTECH LICENSING CONSISTENT WITH THE ANTITRUST RULE OF REASON?}

Alternatively, one could test for patent misuse by examining whether the effects of the behavior are anticompetitive as measured by the antitrust rule of reason. Although the current Federal Circuit misuse standard is

223. See David C. Hoffman, A Modest Proposal: Toward Improved Access to Biotechnology Research Tools by Implementing a Broad Experimental Use Exception, 89 CORNELL L. REV. 993, 1040-41 (2004) (explaining that the Cohen/Boyer patents were licensed widely and nonexclusively to public sector researchers with only minimal royalties assessed if a product made it to the market and that as a result, their pioneering technology was successfully transferred to the commercial sector without hindering the progress of basic research).

224. See id.; Arti K. Rai \& Rebecca S. Eisenberg, Bayh-Dole Reform and the Progress of Biomedicine, 66 LAW \& CONTEMP. PROBS. 289, 300 (2003) (noting that "[m]any observers attribute the rapid progress of the biotechnology industry to the fact that this technology was made widely available rather than licensed exclusively to a single firm”). 
described nominally as distinct from antitrust law, antitrust formulations infuse the analysis. In particular, the Federal Circuit has held that to test for patent misuse, one should look for anticompetitive effects through application of the antitrust rule of reason. ${ }^{225}$ Even under a traditional patent misuse analysis, as applied prior to the Federal Circuit's shift, an antitrust analysis can cast light on concerns that might be shared by patent policy. ${ }^{226}$ One should consider, therefore, whether open source biotech licensing would be consistent with the antitrust rule of reason.

In the antitrust rule of reason, courts look for market power, anticompetitive effects, and proof that the anticompetitive effects outweigh the pro-competitive benefits. ${ }^{227}$ A traditional challenge based on antitrust principles also would have to establish that the open source product and any downstream product constitute two separate products. An improvement on core technology would be more difficult to characterize as a separate product than something invented using an open source research tool. Therefore, an open source agreement that extends to products invented using the research tool is more likely to be suspect under antitrust law than an open source agreement that extends only to improvements in the core technology.

As a starting point, an open source licensing arrangement would not violate the antitrust rule of reason unless the open source product had market power. Many open source products would not have power in a properly defined market because significant substitutes for their products would be available. For example, the open source operating system Linux does not have market power given the availability of other operating systems such as Microsoft Windows.

If an open source group did have market power in a particular product market, one could argue, nevertheless, that the effects of the project are not anticompetitive within the definition of the antitrust rule of reason. For example, the open

225 See supra note 113; see also Windsurfing Int'l, Inc. v. AMF, Inc., 782 F.2d 995, 1001-02 (Fed. Cir. 1986); Bayer AG v. Housey Pharms., Inc., 228 F. Supp. 2d 467 (D. Del. 2002) (applying the Federal Circuit test).

226. See Feldman, supra note 7, at 425-30.

227. See Bd. of Trade of the City of Chi. v. United States, 246 U.S. 231, 238 (1918) ("Every agreement concerning trade, every regulation of trade, restrains. . . The true test of legality is whether the restraint imposed is such as merely regulates and perhaps thereby promotes competition or whether it is such as may suppress or even destroy competition."). 
source arrangement could be characterized as extending beyond the scope of the patent grant by affecting the market for downstream goods. In other words, producers of downstream goods would be restricted by the terms of the open source license. A traditional antitrust rule of reason analysis would focus on whether the open source group is dominating the downstream market with the effect of reducing competition in that market.

On the one hand, the open source group's effects can be characterized as reducing competition in the downstream market. For example, consider the requirement that any version of the core technology that contains downstream improvements must be made available on open terms upstream product. The behavior could be characterized as an attempt to prevent the development of a downstream product, core plus improvement, that is available on terms different from its own. Such behavior potentially could be seen as reducing competition in terms of reducing substitutes for the original patent holder's core products. ${ }^{228}$ Reducing competition for the patent holder's original product could be seen as anticompetitive.

The open source group, however, is not trying to restrict the amount of core plus improvement technology. It is acting to maximize the amount of the improved technology available, by ensuring that the improvements remain openly available. Such an effect would be better described as ultimately increasing rather than reducing the supply of the downstream product.

Moreover, to the extent one might argue that open source licensing requirements discourage downstream innovation, thereby reducing the supply of the downstream product, such concerns would be outweighed by the pro-competitive benefits. Open source licensing produces substantial pro-competitive benefits, including the reduction of patent thickets and an increase in the creation and dissemination of ideas without the type of short-term restriction of supply associated with traditional patenting license arrangements.

228. See, e.g., Dickson v. Microsoft Corp., 309 F.3d 193, 206-07 (4th Cir. 2002) (describing the potential for technology companies to try to dominate a next-generation market to prevent the development of substitutes for its core technology); Robin C. Feldman, Defensive Leveraging in Antitrust, 87 GEO. L.J. 2079, 2090-95 (1999) (arguing that leverage behavior should not be analyzed solely as an attempt to reap additional monopoly profit from a second market but also as an attempt to prevent erosion of the primary monopoly). 
Other traditional allegations of anticompetitive effects could come in the form of a charge that the system resembles a patent pool, the combination of which dominates the core technology market itself. 229 A patent pool is an agreement between patent owners to aggregate intellectual property rights. ${ }^{230}$ In simple pools, each party has the right to use all technology in the pool without paying royalties. ${ }^{231}$ In more sophisticated pools, members may pay royalties based on the relative value of the technology they use or the pool may collect royalties from third parties and distribute those royalties using a schedule that reflects the significance of the technology contributed. ${ }^{232}$

Patent pools may have anticompetitive effects because pools may help participants coordinate price restraints or market divisions. ${ }^{233}$ When parties who are in competition with each other collude to restrain price or divide markets, the behavior constitutes a per se violation of federal antitrust law. 234 In addition, patent pools may facilitate restraints of trade in which the members of the pool coordinate to exclude competition from other sources. 235 Such restraints generally would be tested under the rule of reason. ${ }^{236}$

Patent pools also may have pro-competitive effects. Patent pools may reduce the transaction costs of negotiating rights

229. For a history and analysis of the treatment of patent pools under antitrust law, see Steven C. Carlson, Patent Pools and the Antitrust Dilemma, 16 YALE J. ON REG. 359 (1999).

230. See Atif I. Azher, Antitrust Regulators and the Biopharmaceutical Industry: Compulsory Licensing Schemes Ignoring Gene Therapy Patents' Need, 25 U. PA. J. INT'L ECON. L. 383, 394 (2004); see also FTC/DOJ Guidelines, supra note 203, at 28.

231. See Arti K. Rai, Regulating Scientific Research: Intellectual Property Rights and the Norms of Science, 94 NW. U. L. REV. 77, 129 (1999).

232. See id.

233. See FTC/DOJ Guidelines, supra note 203, at 28.

234. See, e.g., id. (noting that when "pooling arrangements are mechanisms to accomplish naked price fixing ... they are subject to challenge under the per se rule"); see also United States v. New Wrinkle, Inc., 342 U.S. 371, 380 (1952) (finding price-fixing in the context of patent cross-licensing).

235. See FTC/DOJ Guidelines, supra note 203, at 28 (noting access need not be granted to all interested participants); $c f$. United States v. Singer Mfg. Co., 374 U.S. 174, 194-95 (1963) (finding cross-license facilitated broader scheme to exclude competitors).

236. See, e.g., Cont'l T.V. v. G.T.E. Sylvania Inc., 433 U.S. 36, 49 (1977) (noting that the rule of reason is the prevailing standard for testing restraints of trade), on remand to 461 F. Supp. 1046 (N.D. Cal. 1978), aff'd, 694 F.2d 1132 (4th Cir. 1982). 
when patents block each other or the costs of assembling the rights necessary to engage in a particular form of research. ${ }^{237}$ They also may facilitate the exchange of scientific information.

A pooling arrangement could be challenged as patent misuse if the pool dominated a particular market. Although the holder of any one patent may not hold market power, the group as a whole may have power when combining a number of patents that would otherwise compete with each other. In addition, it is possible that a pooling challenge to open source licensing could be framed in the following terms: the relevant market is not the market for an individual technology but the market for the package of licenses necessary to engage in a particular form of research. Within that market, the open source project arguably dominates because no one else holds a full package. Even if the open source project were analyzed as a pool with market power, however, the project would not necessarily violate the antitrust rule of reason. The pooling challenge would be subject to the defenses described above that the effects are not anticompetitive and that any anticompetitive effects are outweighed substantially by the pro-competitive benefits.

\section{CONCLUSION}

Open source biotechnology projects offer the scientific community an opportunity to engage in collaborative research in which the latest advancements in biotechnology are openly available to a broad research community. The restrictions necessary to maintain the open nature of such projects, however, may implicate the doctrine of patent misuse in that they appear to use the power of the patent grant to affect inventions beyond the teachings of the original patent. The proper analysis for determining whether a patent holder's behavior impermissibly extends the scope of the patent grant turns either on whether the effects of the behavior are inconsistent with patent policy or on whether the effects of the behavior fail the antitrust rule of reason. Under either test, however, open source projects should not constitute misuse.

237. See FTC/DOJ Guidelines, supra note 203, at 28; see also Azher, supra note 230, 395-97 (discussing benefits of biotechnology pools). 